\title{
Lost in conversion. Gli archivi fotografici tra analogico e digitale
}

\author{
Carlo Bianchini \\ Alekos Diacodimitri \\ Marika Griffo
}

Abstract

L'esperienza di ricerca qui presentata si inserisce all'interno di $3 R e a D$, un progetto finanziato dal Fondo Europeo di Sviluppo Regionale nell'ambito del programma operativo 20 I 4-2020 della Regione Lazio e sviluppato da un'aggregazione che coinvolge Sapienza Università di Roma, Link Campus University, Corvallis spa e Teleconsys SrI [I] In questo contesto, parte della ricerca si è indirizzata allo studio della gestione dei diversi formati e supporti di immagini fotografiche utilizzabili. Ciò ha portato alla possibilità di esplorare i processi di acquisizione digitale di tutti quegli archivi analogici al fine di ottenere materiale utilizzabile nel progetto. La sperimentazione condotta ha preso in esame diversi tipi di supporto di immagini analogiche per definire le strategie di acquisizione in grado di garantire il più elevato legame di corrispondenza tra l'originale e la sua copia digitale.Tra i casi studio analizzati, la sperimentazione ha riguardato l'elaborazione, tramite processi fotogrammetrici digitali, delle scansioni e la validazione, in termini di rispondenza metrica e morfologica dei risultati ottenuti. II tema si innesta in una riflessione più ampia su quanto dati e modelli della documentazione si predispongano ad essere riutilizzati e, soprattutto, quali siano le condizioni affinché ciò possa avvenire.

Parole chiave

fotografia analogica, fotogrammetria, 3D modelling, integrazione dati, digitalizzazione.
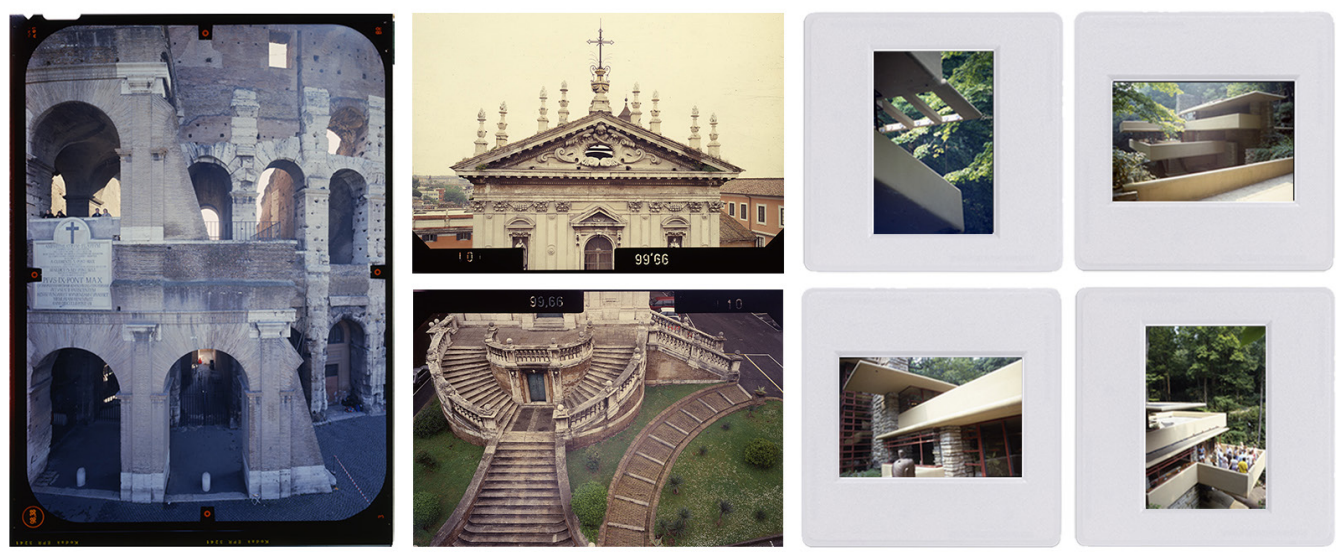


\section{3reaD ed i modelli integrati}

II progetto 3reaD si pone l'obiettivo di realizzare un set completo di strumenti informatici per il rilievo per gestire la generazione, l'analisi e l'elaborazione dei dati riguardanti lo stato di conservazione del patrimonio culturale architettonico, archeologico e storico-artistico. II progetto, nelle sue varie fasi, prevede l'elaborazione di una piattaforma informatica online capace di generare un modello metrico tridimensionale dettagliato a partire da un rilievo fotogrammetrico di un bene culturale. Mettendo a sistema le informazioni derivate dagli open database con quelle dedotte eseguendo una mappatura del danno direttamente sul modello 3D, la piattaforma permette la valutazione dello stato di conservazione del bene in questione. La piattaforma $3 R e a D$ consentirà quindi di caricare su uno spazio cloud immagini fotografiche ed informazioni di anagrafica del bene per restituire modelli 3D informativi e modelli previsionali. A questo scopo, il presente contributo mira a focalizzare l'attenzione sul tema della digitalizzazione del patrimonio e sulle complessità metodologiche e procedurali connesse.

\section{Documentazione per immagini}

Ripercorrendo rapidamente i grandi mutamenti registrati nell'ultimo trentennio di sviluppo tecnologico, registriamo quanto la pratica architettonica di rilievo e rappresentazione, le operazioni di documentazione del patrimonio fino alla catalogazione ed archiviazione di materiale eterogeneo ne siano state gradualmente condizionate. Osservato più da vicino, questo scenario ci restituisce, da un lato, una rassicurante riconoscibilità e comparabilità di metodologie, procedure e standard di controllo, dall'altro, ci pone di fronte l'evidenza di quanto questi trenta anni abbiano profondamente mutato strumenti di acquisizione e supporti di archiviazione.

Aldilà delle operazioni di esclusiva digitalizzazione di produzioni analogiche, questo enorme patrimonio possiede in potenza una sua vitalità capace di produrre nuova conoscenza inserendosi ed amalgamandosi nei processi digitali.

Venendo all'ambito della documentazione del patrimonio costruito, quest'operazione di coesione e, se vogliamo, di collaborazione tra i dati analogici e digitali ha il proprio fondamento nella trasparenza di comunicazione di metodi, procedure e risultati. Quanto più la trasmissione di quest'apparato informativo archiviato risulti puntuale tanto più l'usabilità dei dati sarà elevata. Ciò è particolarmente calzante per tutti quei processi di conoscenza basati su applicazione del metodo scientifico, il cui principio primo si incardina proprio nella riproducibilità delle procedure utilizzate e delle condizioni d'ambiente. La sperimentazione condotta riguarda più da vicino la documentazione, analogica, analitica e digitale, raccolta ed elaborata per il rilievo architettonico. Questa sperimentazione tenta di avviare una riflessione su due aspetti; il primo riguarda la definizione di procedure standardizzate per l'acquisizione di immagini da supporti analogici e la loro corretta gestione ed archiviazione digitale; il secondo tema, invece, indaga la possibilità di generare nuovi modelli conoscitivi bidimensionali e tridimensionali a partire proprio da tale apparato documentale.

\section{Tra analogico e digitale: buone pratiche per la conversione}

Al fine di ottenere immagini digitali integrabili nel processo di 3ReaD, è stato messo a punto un protocollo di acquisizione che tiene conto dei differenti formati di supporto fisico da scansionare e delle caratteristiche delle camere utilizzate per gli scatti. Il protocollo prevede l'acquisizione degli originali fisici attraverso l'uso di uno scanner fotografico professionale. Per l'esperienza presentata in questa ricerca, è stato utilizzato uno scanner Epson Perfection V700 PHOTO [2]. La principale complessità in fase di scansione riguarda la perfetta e controllata planarità della superficie da acquisire, al fine di generare una copia digitale corrispondente all'originale non solo dal punto di vista cromatico ma anche da quello geometrico e 


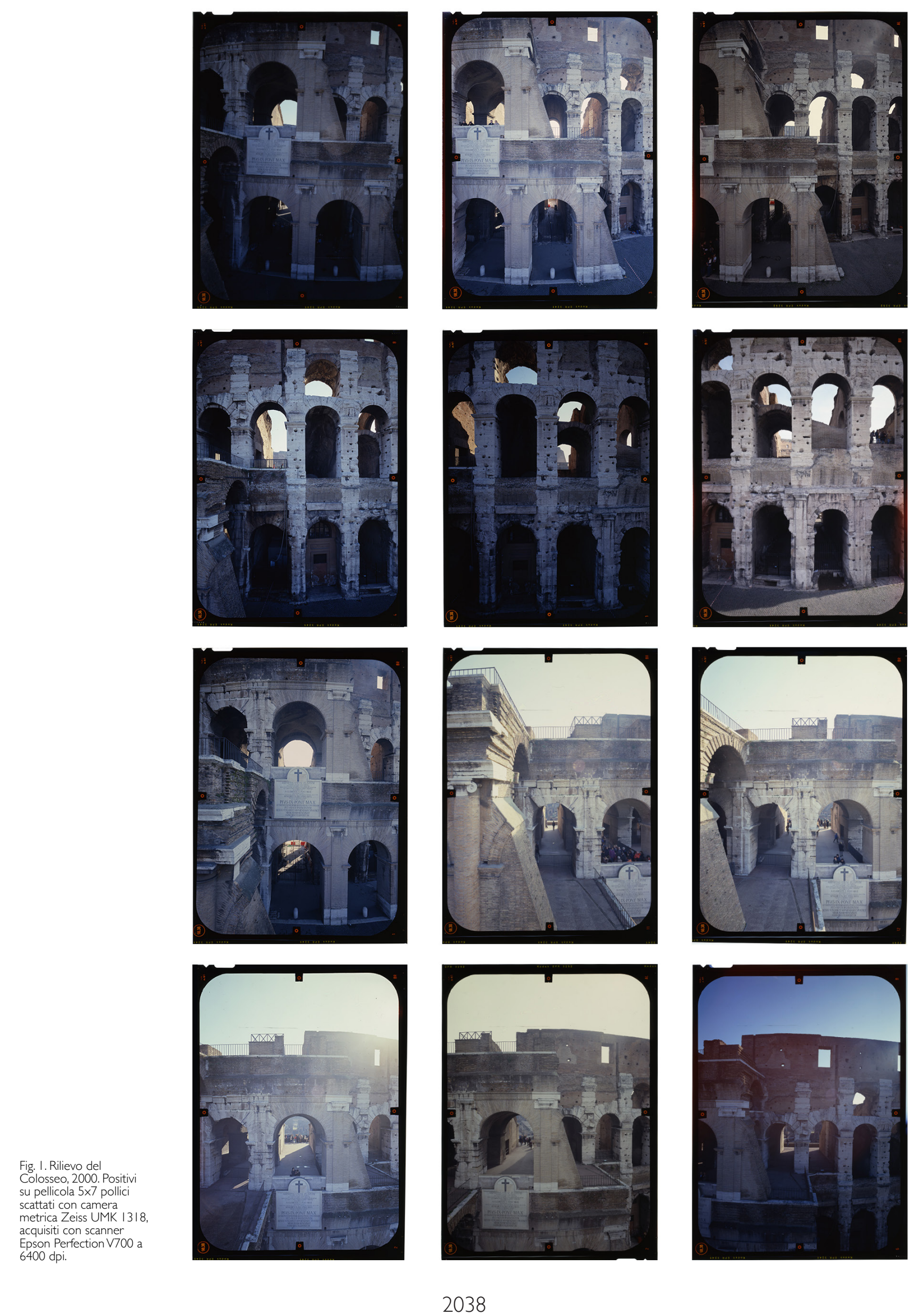


Fig. 2. Rilievo del

Colosseo, 2000. Positivo su pellicola $5 \times 7$ pollici.

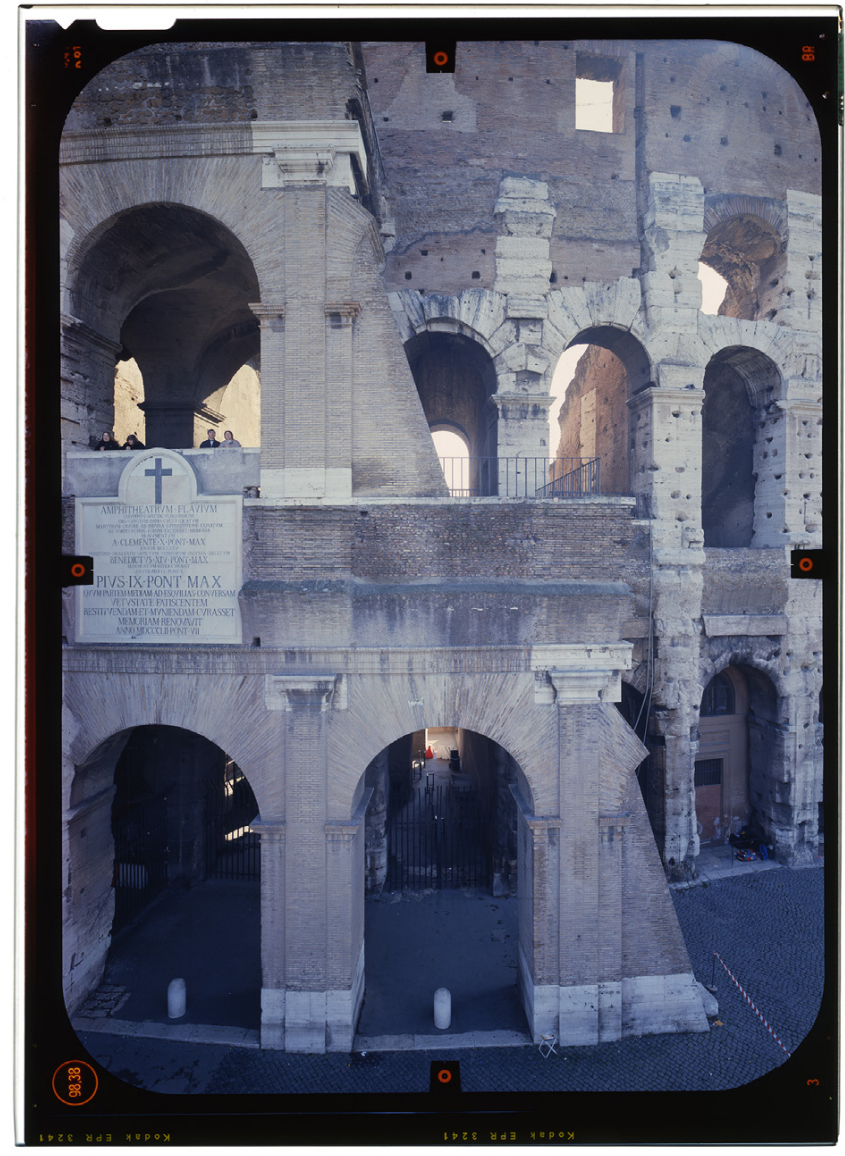

morfologico. Questo requisito è il presupposto necessario per le applicazioni digitali, tra cui la fotogrammetria, legate allo studio metrico e proporzionale dell'immagine. I portapellicola risolvono con un buon margine di approssimazione questi problemi, pur non garantendo una stesura uniforme delle immagini su supporti troppo compromessi o deteriorati. II software utilizzato è quello di sistema - Epson Scan - che consente di accedere e modificare tutte le funzionalità e i settaggi di scansione al fine di garantire un maggiore controllo su tutta l'operazione.

Il concetto alla base di tutte le considerazioni fatte sul processo di scansione, è la possibilità di stimare il valore corretto di risoluzione necessario durante l'acquisizione dell'immagine, al fine di non perdere tutte le informazioni dalla fotografia analogica necessarie alle fasi successive della sperimentazione. Alla pellicola analogica, infatti, non è applicabile il concetto di risoluzione, caratteristica propria dei supporti digitali. In questo contesto, la risoluzione è definita come quella grandezza che quantifica il grado di dettaglio di unsimmagine, in funzione del numero di pixel compresi per ogni unità di misura (Pixels Per Inch). Seppur non perfettamente comparabili, la proprietà delle fotografie analogiche che più si avvicina al concetto di risoluzione, è quella di nitidezza dell'immagine [3]. La nitidezza rappresenta la capacità dell'occhio umano di essere in grado di distinguere il numero di coppie di linee ad alto contrasto contenute in ogni millimetro dell'immagine. Questa qualità si esprime quindi in coppie di linee per millimetro, o lp/mm, (line pairs per millimiter). Convenzionalmente, l'occhio umano viene considerato come capace di distinguere all'incirca $6 \mathrm{lp} / \mathrm{mm}$ in condizioni ottimali, da ciò deriva la consuetudine di considerare un valore di 300 dpi come ottimale al fine di una buona qualità di stampa. Uno scanner con una risoluzione dichiarata di 6400 dpi può discernere fino a 125 coppie di linee per millimetro, ma test di misurazione sullo scanner utilizzato per la sperimentazione hanno dimostrato che le linee effettivamente osservabili non superano le 40/45, per una risoluzione reale di circa 3200 dpi. 

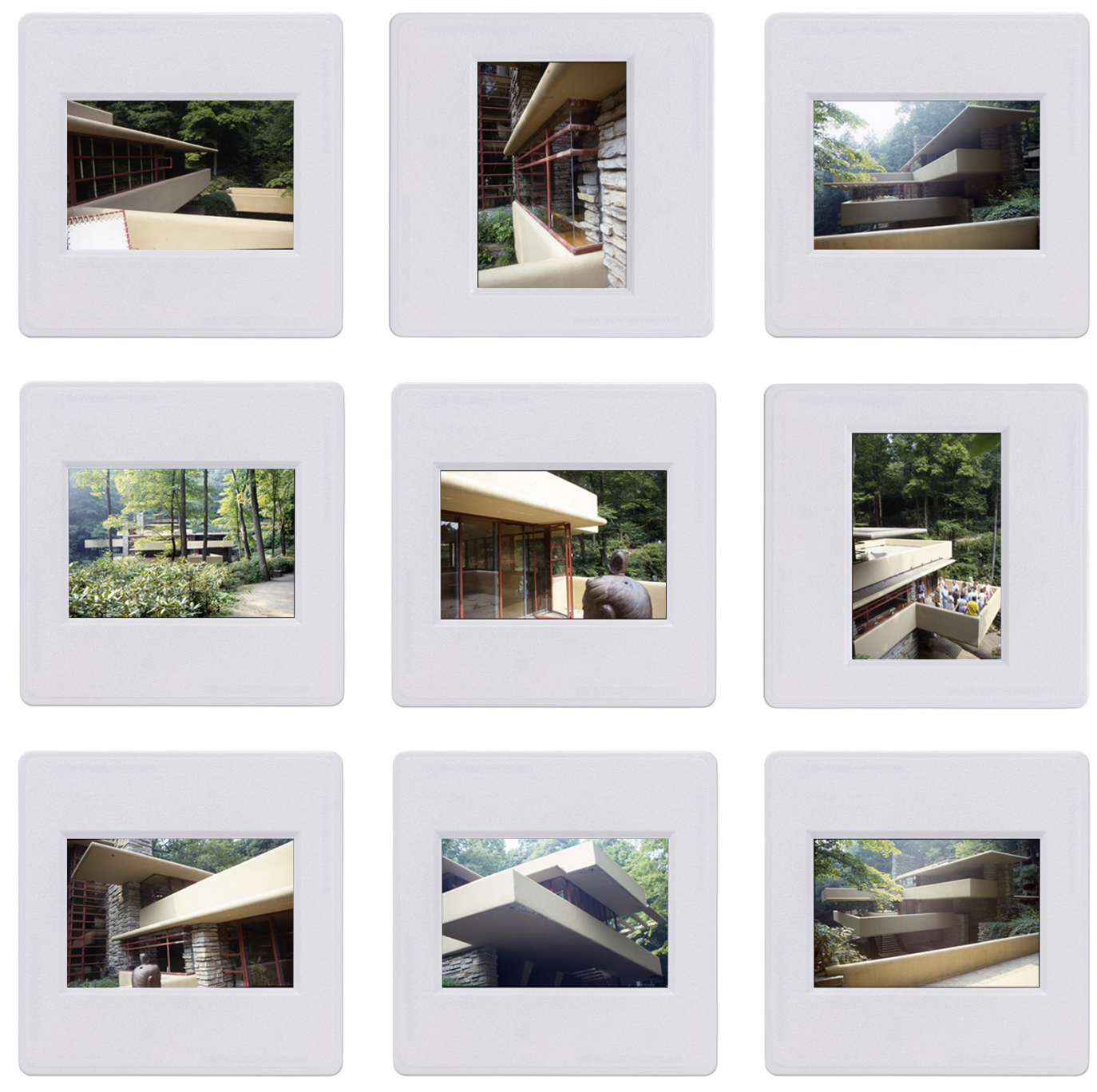

Fig. 3. Casa Kaufmann (Frank Lloyd Wright, 1939). Diapositive $35 \mathrm{~mm}$ scattate dall'autore ne 1987, scansioni a 6400 dpi.
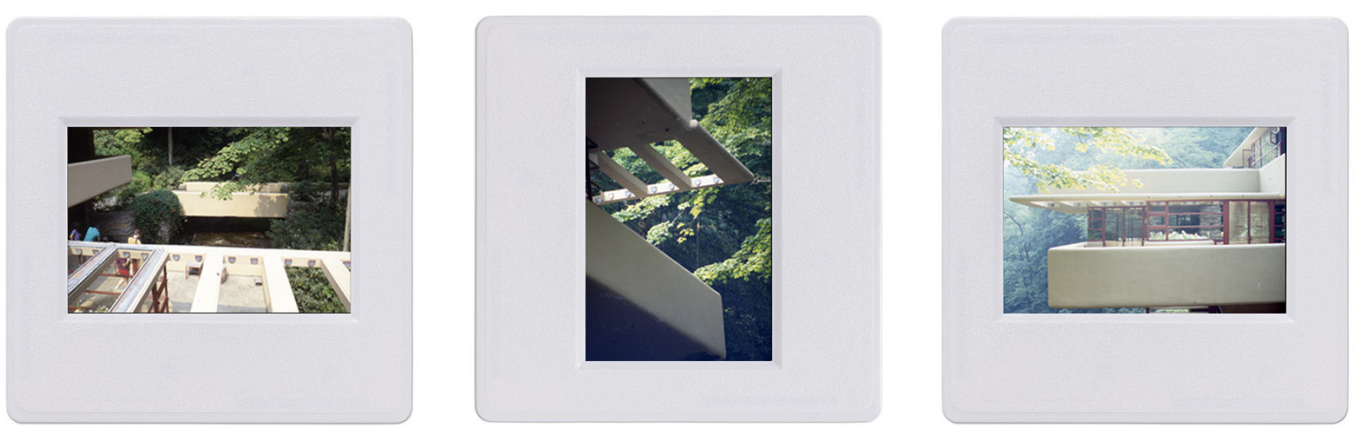

Moltiplicando la larghezza della pellicola in millimetri per il valore della nitidezza espresso in l/mm moltiplicato per 2 (per le coppie di linee) e facendo lo stesso procedimento per l'altezza, possiamo ottenere il valore massimo di risoluzione con il quale, in condizioni ottimali, un positivo può essere scansionato senza perdita di informazioni.

$$
[(\mathrm{lpm} \times \mathrm{B} \times 2) \times(\mathrm{Ipm} \times \mathrm{H} \times 2)] / 1.000 .000
$$

Tale calcolo approssimato deriva dal il teorema del campionamento di Nyquist-Shannon, il quale definisce la minima frequenza, necessaria per campionare un segnale analogico senza perdere informazioni [4]. 


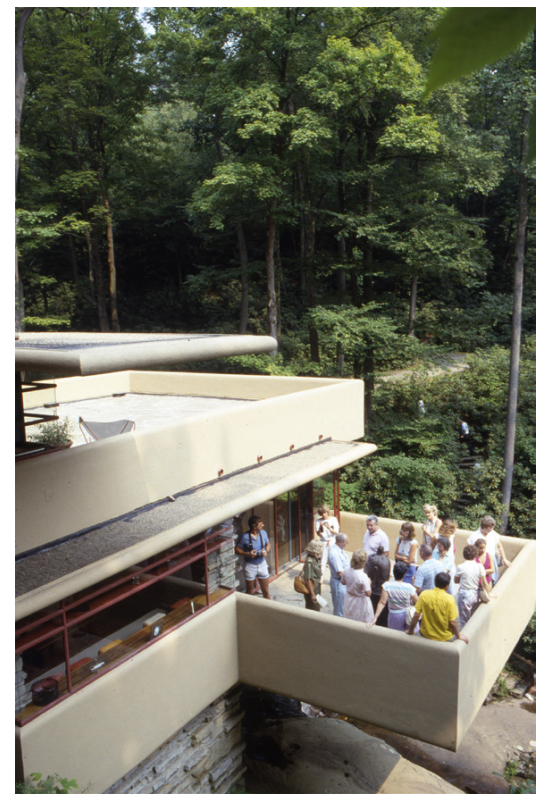

Queste risoluzioni teoretiche trovano però un riscontro applicativo più articolato. Nelle immagini analogiche, la risoluzione dipende dalla sensibilità della pellicola utilizzata, mentre nel digitale le variabili sono legate non solo al numero di pixel del sensore, ma anche dal tipo di rielaborazione effettuata dal software, peculiare per ogni marca di fotocamera. Molti altri fattori entrano in gioco, come la disposizione regolare dei pixel del sensore, rapportata a quella dei granuli di argento. Inoltre, nei sensori molto spesso la risoluzione dichiarata non è uniforme, ma interpolata a zone. Considerazioni di carattere empirico tra fotografi portano a considerare, per pellicole 35mm, risoluzioni massime di acquisizione di 15 Megapixel [5]. Premesso ciò, la sperimentazione è stata effettuata sui materiali relativi a differenti campagne di rilievo fotogrammetrico, in maniera tale da avere a disposizione un campionario eterogeneo di formati immagine.

Il primo caso studio riguarda le immagini di archivio acquisite durante una campagna di rilievo del Colosseo, nel 2000. La campagna di rilevamento fotogrammetrico è stata realizzata con camera metrica Zeiss UMK I 3 8, pellicola 5x7pollici Kodar EPR 3241. Essendo un formato non standard di acquisizione, è stato utilizzato un sistema a pressione con una lastra di vetro che garantisce un piano di acquisizione omogeneo ed elimina le increspature della pellicola. Tale lastra è stata utilizzata insieme alla film area guide, una cornice flessibile per pellicole fino all' $8 \times 10$ ', da appoggiare direttamente sul vetro dello scanner.

Una seconda applicazione ha riguardato l'acquisizione in digitale di diapositive $35 \mathrm{~mm}$. Le immagini, di tipo amatoriale acquisite mediante una fotocamera analogica Olympus m20, ritraggono la celebre casa Kaufman di Frank Lloyd Wright. In questo caso, il formato standard ha consentito l'impiego del portapellicola in dotazione. In questo caso, la dimensione contenuta del supporto ha favorito il controllo della planarità della superficie acquisita.

Il terzo campione di immagini ha riguardato l'archivio di fotografie metriche del rilievo della chiesa dei Santi Domenico e Sisto a Roma, svolto nel 1998. In questo caso, il formato della pellicola è adatto all'uso dei frame portapellicola standard dello scanner, senza necessità di soluzioni ulteriori.

Per tutti i campioni sono state sperimentate diversi valori di digitalizzazione della diapositiva: 300dpi, I600dpi, 3200dpi e 6400dpi (massima risoluzione, 28864×22933 pixel, dimensioni del file $\pm 2 \mathrm{~GB})$.

Le diverse acquisizioni sono state tra loro comparate per valutare il limite oltre il quale un aumento di risoluzione della scansione non comporti un significativo incremento di dati acquisiti. In base a queste considerazioni, la risoluzione di acquisizione di 3200 dpi risulta essere ottimale per tutti i formati di immagini analizzati. 

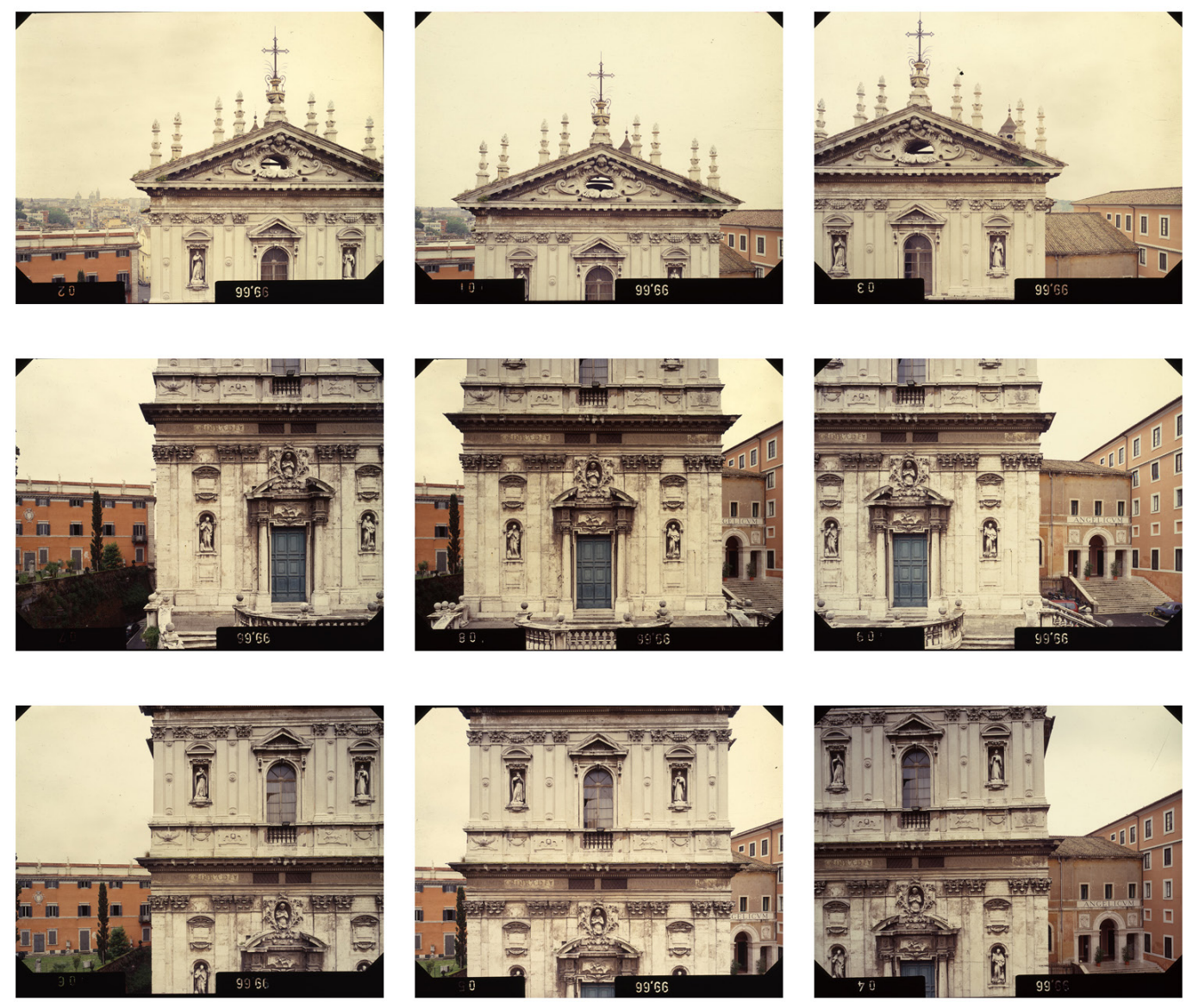

Fig. 5. Rilievo della chiesa dei SS. Domenico e Sisto, 1998. Positivi su pellicola $5 \times 4$ pollici scattati con camera metrica Wild P3I, acquisiti con scanner Epson Perfection $\vee 700$ $6400 \mathrm{dpi}$.
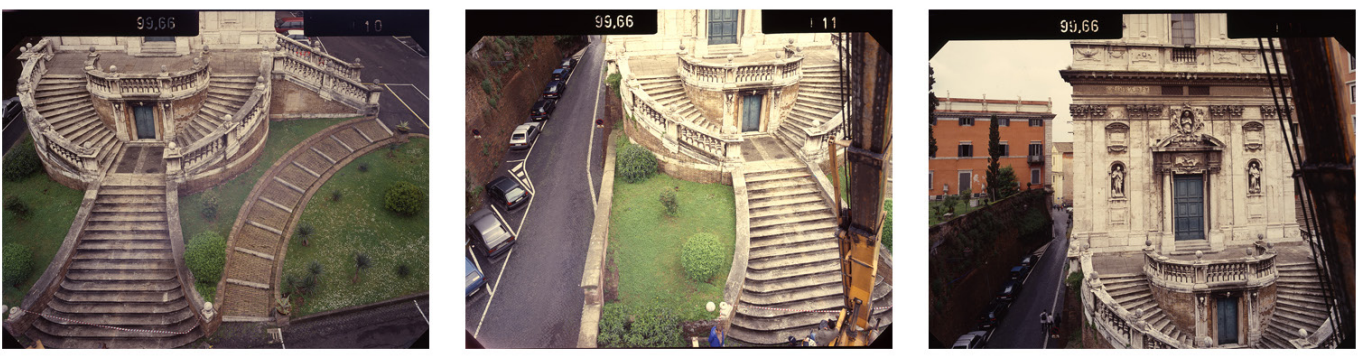

Nuovi modelli per vecchie acquisizioni

Le procedure di acquisizione precedentemente discusse sono il presupposto necessario per la fase successiva di elaborazione. Qui presentiamo le operazioni di sistematizzazione di dati per la produzione di nuovi modelli condotte sulla chiesa dei Santi Domenico e Sisto a Roma. La documentazione disponibile sul manufatto risale ad una campagna di rilievo fotogrammetrico condotta nel 1998 integrando l'acquisizione topografica d'appoggio con quella fotografica [6]. L'utilizzo di tecniche di fotogrammetria analitica aveva permesso la restituzione di modelli vettoriali 2D in scala 1:50 per una lettura di tutti i caratteri architettonici. II sistema di codifica grafica utilizzato trasmette efficacemente il livello di affidabilità di restituzione per ogni elemento disegnato. Dopo la prima fase di ricognizione di tutto il materiale disponibile, la fase successiva ha avuto come obiettivo l'elaborazione di un modello numerico tramite applicazioni di Structure from Motion e, a partire da esso, di un'orto-immagine di comparazione per valutare la rispondenza morfometrica rispetto ai modelli del 1998. L'utilizzo di una camera metrica e la lettura dei valori dei punti fiduciali delle pellicole ha consentito una precisa calibrazione delle immagini acquisite. In questa fase, sono 

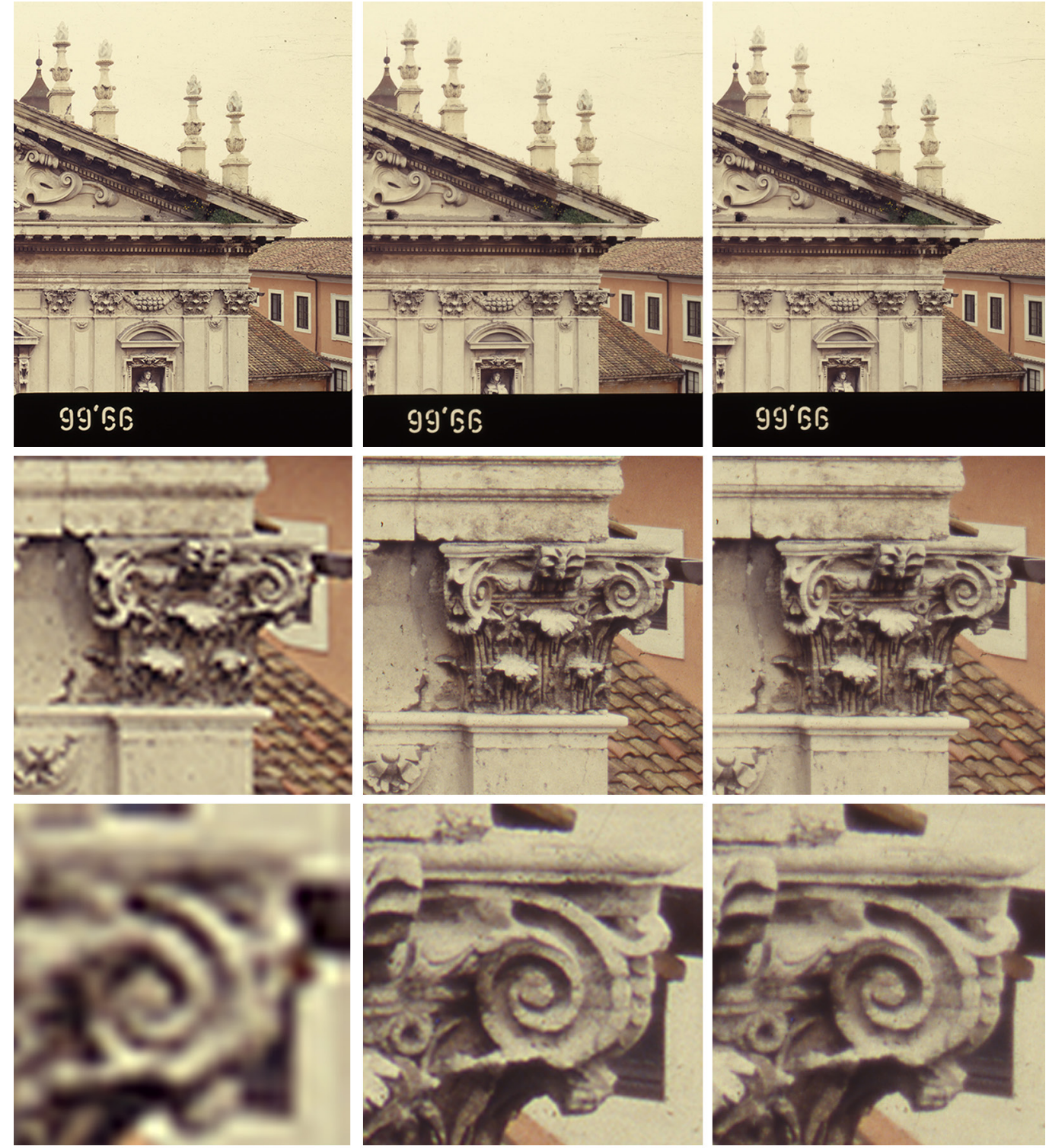

Fig. 6. Rilievo della chiesa dei SS. Domenico e Sisto, 1998. Confronto tra scansioni acquisite a 300dpi (|354x 075 pixe peso $2,5 \mathrm{MB}), 3200 \mathrm{dpi}$ (7219x5732 pixel, peso $70 \mathrm{MB})$ e 6400dpi
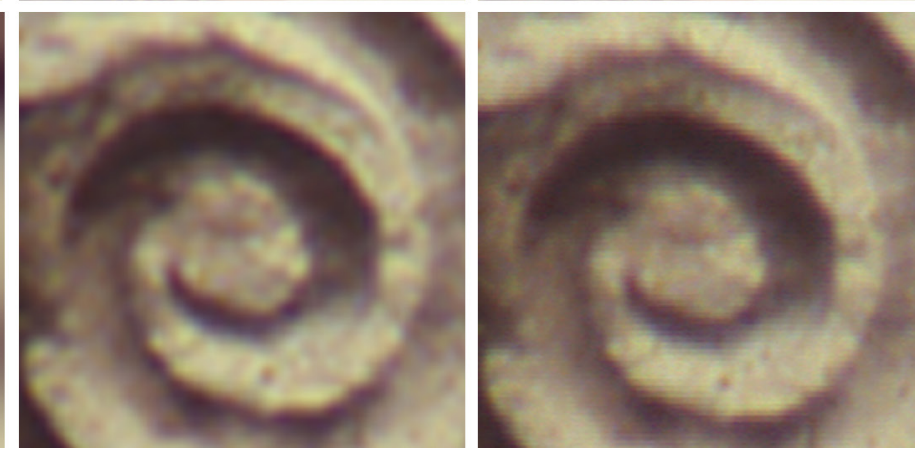


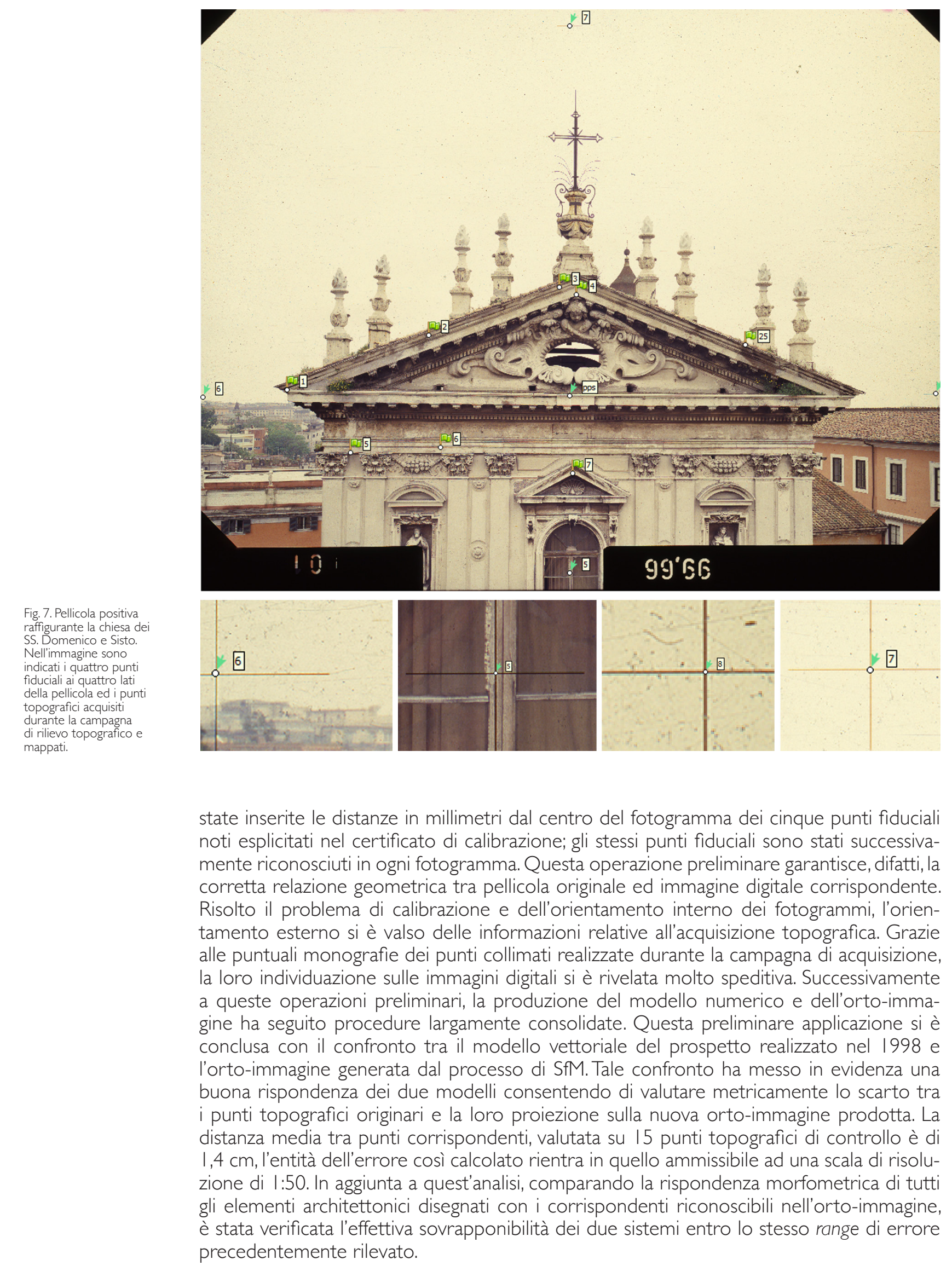


Fig. 8. Sulla sinistra, la camera metrica Wild P3I (<http://www. wild-heerbrugg.com photogrammetry $\mathrm{htm}>$ ). Sulla destra, certificato di calibrazione della camera con lo schema esemplificativo della posizione dei punti fiduciali e dei punti principali di simmetria e auto collimazione rispetto alla croce centrale impressa sulla pellicola.

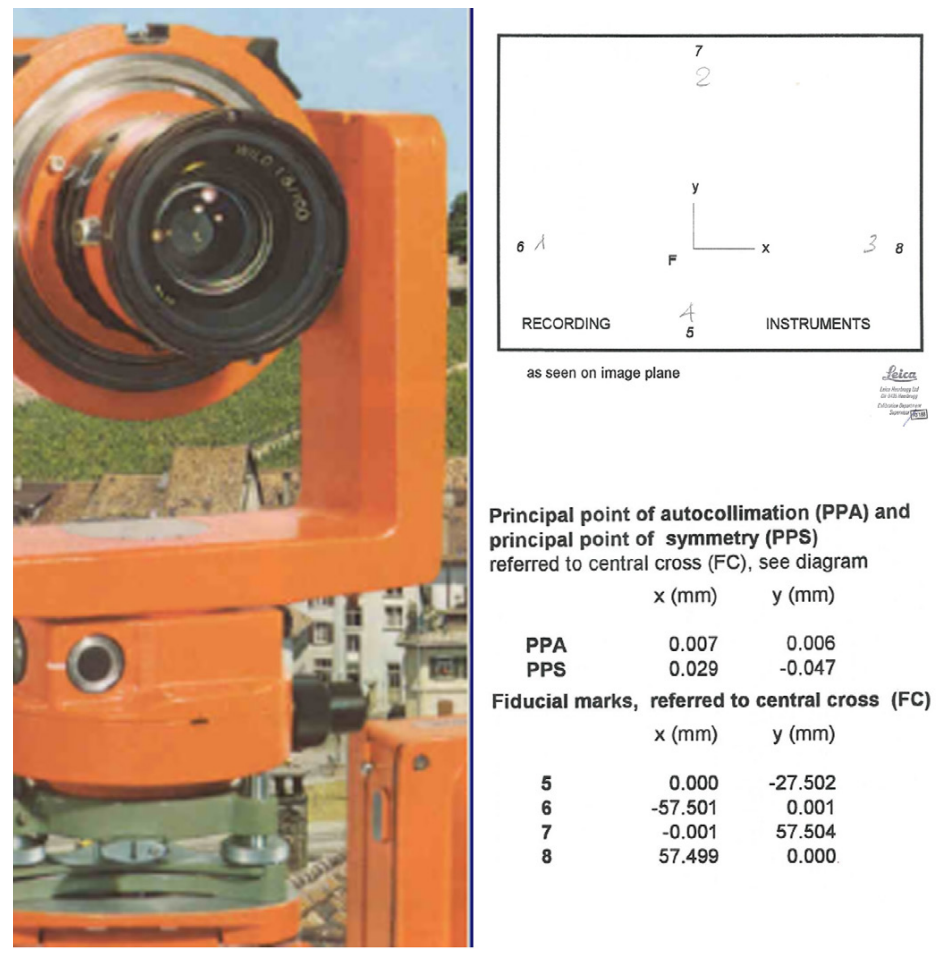

\section{Conclusioni}

Le nuove frontiere del digitale lanciano sfide sempre più complesse proiettandosi verso sistemi di gestione di enormi quantità di dati e di metodologie di estrazione di informazioni sempre più efficaci. È difficile nascondere l'entusiasmo di fronte prospettive di avanzamento tanto dirompenti, risulta altresì difficile non provare ad immaginare prima, e sperimentare poi, applicazioni e ricadute nei più eterogenei settori di ricerca. Di fronte queste considerazioni nasce però l'esigenza di validare e recuperare dati, informazioni e modelli già esistenti fornendo loro una nuova vita digitale. Queste trasformazioni hanno portato spesso a mettere da parte ciò che era stato già raccolto ed archiviato in favore di una nuova documentazione born-digital. In una direzione forse un po' meno battuta ma altrettanto significativa, il contributo ha avuto l'obiettivo di immaginare e sperimentare nuovi utilizzi e nuovi esiti di una quantità notevole di dati, informazioni e modelli ereditati da un passato non sempre così remoto.

\section{Note}

[l] < http://3read.it/> (consultato il 6 maggio 202I),

[2] Scanner piano a due obiettivi con sensore da 6400 dpi, range di scansione di $216 \mathrm{~mm} \times 297 \mathrm{~mm}$ e profondità di colore di 48 Bit. Lo scanner è dotato inoltre di una serie di supporti porta pellicola per i differenti formati da acquisire: $35 \mathrm{~mm}$ in striscia, diapositive 35mm intelaiate, 120 in striscia, formato 4×5" e Film Area Guide. Per un approfondimento sulle qualità dello scanner utilizzato si rimanda a <http://www.effeunoequattro.net/htdocs/freecontent/FC_ProvaV700/index.htm> (consultato il 6 maggio 202I).

[3] <http://www.aristidetorrelli.it/Articoli/RisoluzionePellicolaDigitale/RisoluzionePellicolaDigitale.htm e https://www.kenrockwell.com/tech/film-resolution.htm> (consultato il 6 maggio 202I).

[4] <https://clarkvision.com/imagedetail/sampling |/> (consultato il 6 maggio 202 I).

[5] <http://www.stagniweb.it/scan0l.htm> (consultato il 6 maggio 202I).

[6] II rilievo fotogrammetrico è stato condotto grazie ad un contratto di ricerca affidato al Dipartimento di Rappresentazione e Rilievo dell'Università di Roma "La Sapienza" con il coordinamento scientifico del prof. Riccardo Migliari. Le operazioni hanno riguardato la facciata principale dell'edificio e sono state condotte utilizzando una camera metrica Wild P3I con focale 99.66 per l'acquisizione fotografica, la stazione totale Wild I 800 per il rilievo. 


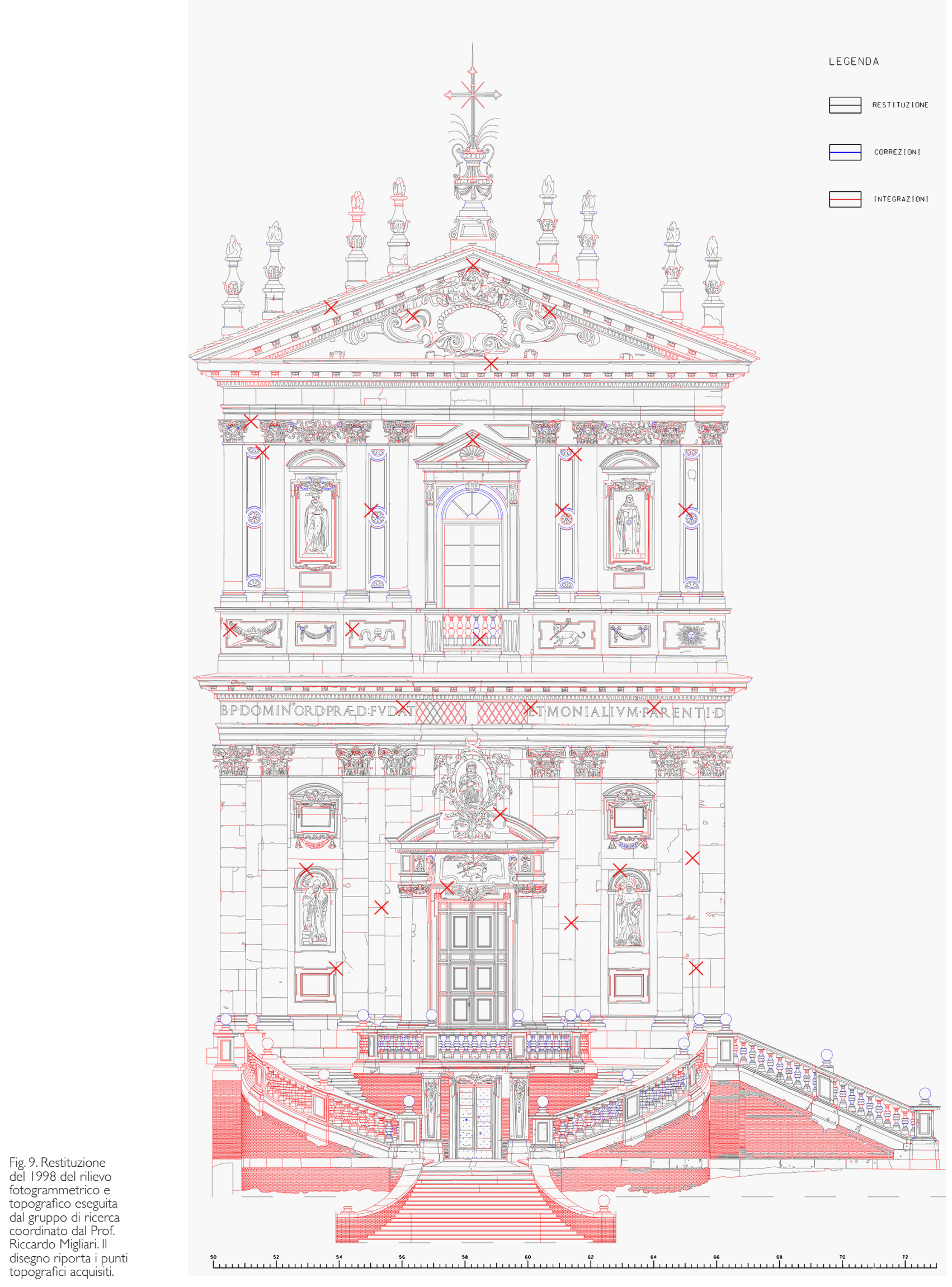




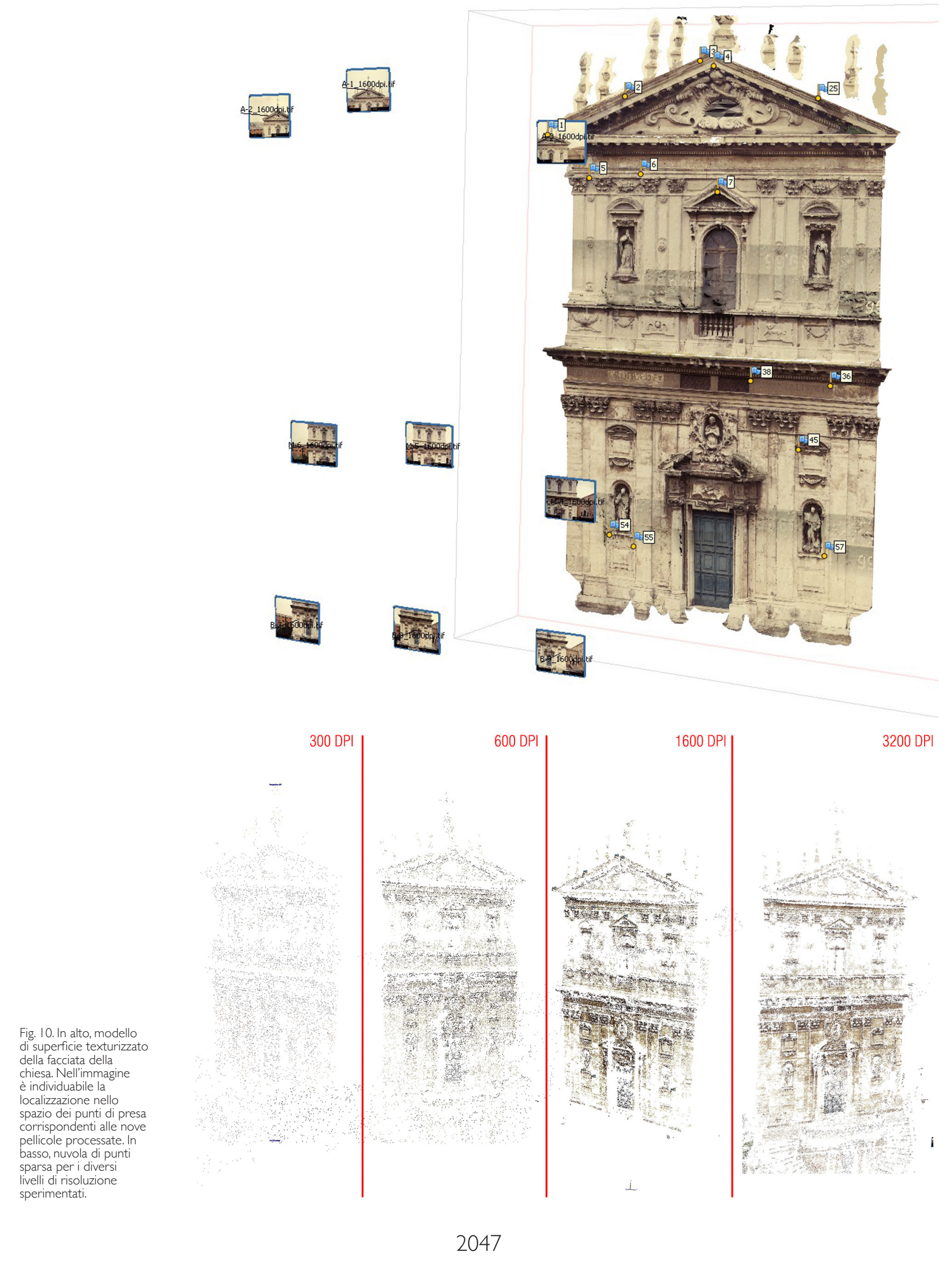


Fig. I I Sulla sinistra, l'ortoimmagine realizzata tramite process fotogrammetrici digitali. A destra, sovrapposizion della restituzione de 1998 con l'ortoimmagine per la verifica metrica e morfologica dei due elaborati.

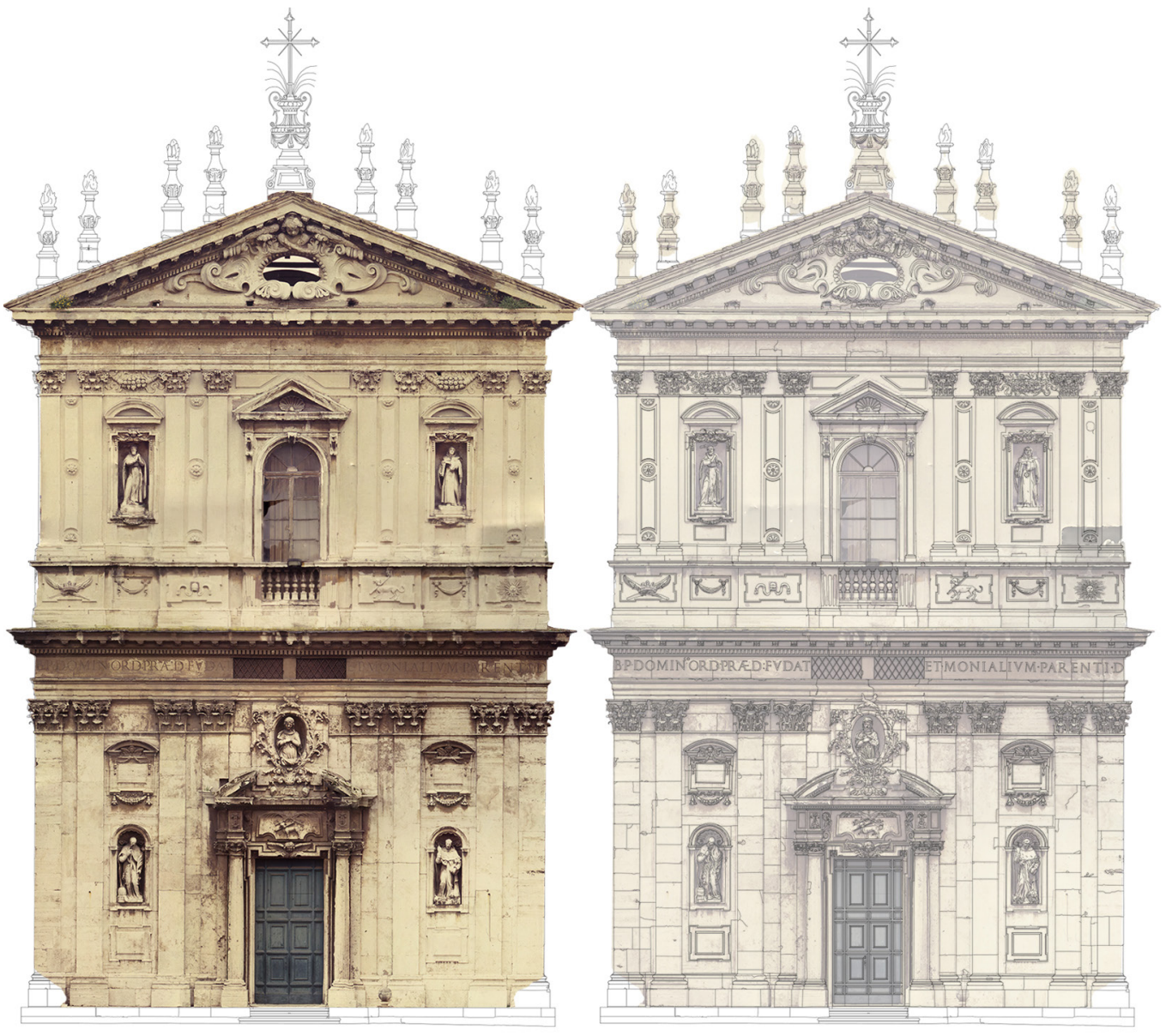

$0 \mathrm{~m}$

$10 \mathrm{~m}$
$30 \mathrm{~m}$

\section{Riferimenti bibliografici}

Bianchini C. (20I2). Rilievo e Metodo Scientifico.Survey and Scientific Method. Elogio della Teoria. Identità delle discipline del Disegno e del Rilievo. Roma: Gangemi Editori.

Carpiceci M. (2012). Fotografia digitale e architettura. Storia, strumenti ed elaborazioni con le odierne attrezzature fotografiche e informatiche, pp. 94- I |4. Roma: Aracne Editrice.

Dlesk D., Uueni A., Vach K. et al. (2020). From Analogue to Digital Photogrammetry: Documentation of Padise Abbey in Two Different Time Stages. In MDPI Applied Science, n. I0(23), 8330, pp. I- I 6.

Dlesk A., Vach K., Pavelka K. (2020). Structure from motion processing of analogue images captured by Rollei metric camera, digitized with various scanning resolution. In Acta Polytechnica, 2020, 60.4, pp. 288-302.

Nichols J., Fong D., Avey S. (20 I 6). Re-Envisioning Lost Built Cultural Heritage: POST-Tsunami Aceh. In International Conference on Engineering and Science for Research and Development (ICESReD). Proceeding Banda Aceh international conference on engineering and science for research and development. Banda Aceh - Indonesia October 25, 26, 20 I 6, pp. 83-93.

Valenti G. M. (2019). Digital models: divulgation and dissemination. In Parrinello S. Digital \& Documentation. Databases and Models for the enhancement of Heritage, pp. 44-55. Pavia: Pavia University Press.

Autori

Carlo Bianchini, Sapienza Università di Roma, carlo.bianchini@uniromal.it

Alekos Diacodimitri, Sapienza Università di Roma, alekos.diacodimitri@uniromal.it

Marika Griffo, Sapienza Università di Roma, marika.griffo@uniromal.it

Per citare questo capitolo: Bianchini Carlo, Diacodimitri Alekos, Griffo Marika (2021). Lost in conversion. Gli archivi fotografici tra analogico e digitale/ Lost in Conversion. Photographic Archives between Analogue and Digital. In Arena A., Arena M., Mediati D. Raffa P. (a cura di) Connettere Un disegno per annodare e tessere Linguagoi Distanze Tecnologie. Atti del $42^{\circ}$ Convegno Internazionale dei Docenti delle Discipline della Rappresentazione Connecting Drawing for weaving relationship. Languages Distances Technologies. Proceedings of the 42 th International Conference of Representation Disciplines Teachers. Milano: FrancoAngeli, pp. 2036-2061. 


\title{
Lost in Conversion. Photographic Archives between Analogue and Digital
}

\author{
Carlo Bianchini \\ Alekos Diacodimitri \\ Marika Griffo
}

Abstract

The research experience presented here is part of $3 R e a D[I]$, a project funded by the European Regional Development Fund within the 2014-2020 operational program of the Lazio Region. It is developed by an aggregation involving Sapienza University of Rome, Link Campus University, Corvallis spa and Teleconsys Srl. In this context, part of the research was addressed to the study of how to manage and work with different formats and supports of photographic images. This led explore the digital acquisition processes of all those analog archives in order to obtain material that could be used within the project. The experimentation examined different types of analogue image supports in order to define the acquisition strategies able to guarantee the highest correspondence between the original and its digital copy. Among the case studies here presented, the experimentation concerned the processing, through digital photogrammetric processes, of the scans and the validation, in terms of metric and morphological correspondence of the results. The topic is part of a broader reflection on how much data and models of the documentation are ready to be reused and, above all, what are the conditions for this to happen.

Keywords

analog photography, photogrammetry, 3D modelling, data integration, digitization.

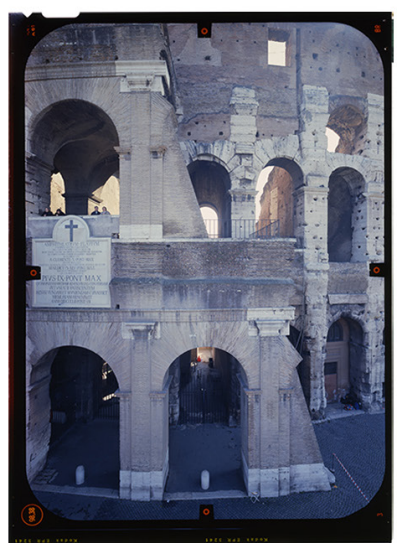

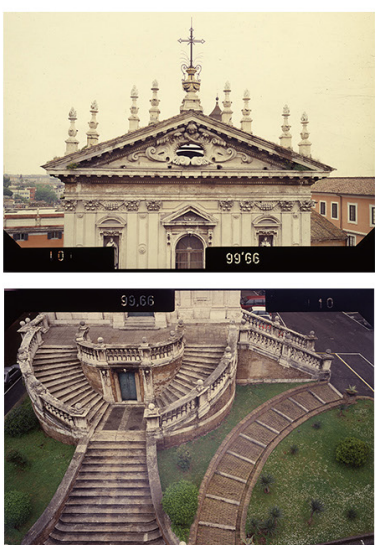
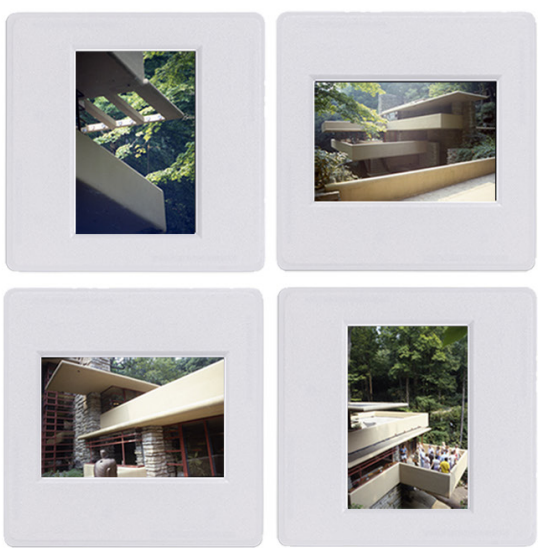


\section{3reaD and interconnected models}

The 3reaD project aims to create a complete set of IT tools to support documentation of the state of conservation of architectural, archaeological and historical-artistic cultural heritage through systems able to collect, process and store heterogeneous data. The project, in its various phases, foresees the elaboration of an online computer platform able to generate a detailed three-dimensional metric model starting from a photogrammetric survey of a cultural heritage. By linking together information derived from open databases with those deduced by performing a mapping of decay phenomena directly on the 3D model, the platform allows the assessment of the building state of conservation and risk. The 3ReaD platform will then allow to upload on cloud photographic images and alphanumerical information of the object to build informative 3D models and predictive models as well. With this aim, this paper aims to focus on the theme of heritage digitization and the methodological and procedural complexities involved.

\section{Documentation through images}

Looking back at the great changes that have taken place in the last thirty years of technological development, we can see how much they affected the architectural practice of survey and representation, the operations of documentation of the heritage and the cataloguing and archiving of heterogeneous material. On a closer look, this scenario gives us, on the one hand, a reassuring recognizability and comparability of methodologies, procedures and standards, on the other hand, it sheds light on how much these thirty years have profoundly changed acquisition tools and archiving supports.

Beyond the mere digitization of analogical productions, this enormous heritage has its own potential vitality, capable of producing new knowledge by being inserted and amalgamated in digital processes.

In the field of documentation of the built heritage, this operation of cohesion and, if we want, of collaboration between analog and digital data has its foundation in the transparency of communication of methods, procedures and results. The more accurate the transmission of this archived information, the more usable the data will be. This is particularly true for all those knowledge processes based on the application of the scientific method, whose first principle hinges on the reproducibility of the procedures used and the environmental conditions. The experimentation conducted concerns more closely the documentation, analogical, analytical and digital, collected and processed for the architectural survey. This experimentation attempts to start a reflection on two aspects; the first concerns the definition of standardized procedures for the acquisition of images from analogical supports and their correct digital management and archiving; the second theme, instead, investigates the possibility of generating new two-dimensional and three-dimensional models starting from this documentary apparatus.

\section{Between analog and digital: best practices for conversion}

In order to obtain digital images that can be integrated into the 3 ReaD process, we have developed an acquisition protocol which takes into account the different formats of physical supports to be scanned and the characteristics of the cameras used for the shots. The protocol involves the acquisition of the physical originals through the use of a professional photographic scanner. For the experience presented in this research, an Epson Perfection V700 PHOTO scanner was used [2]. The main complexity in the scanning phase concerns the perfect and controlled flatness of the surface to be acquired, in order to generate a digital copy corresponding to the original not only from the chromatic point of view but also from the geometric and morphological one. This 

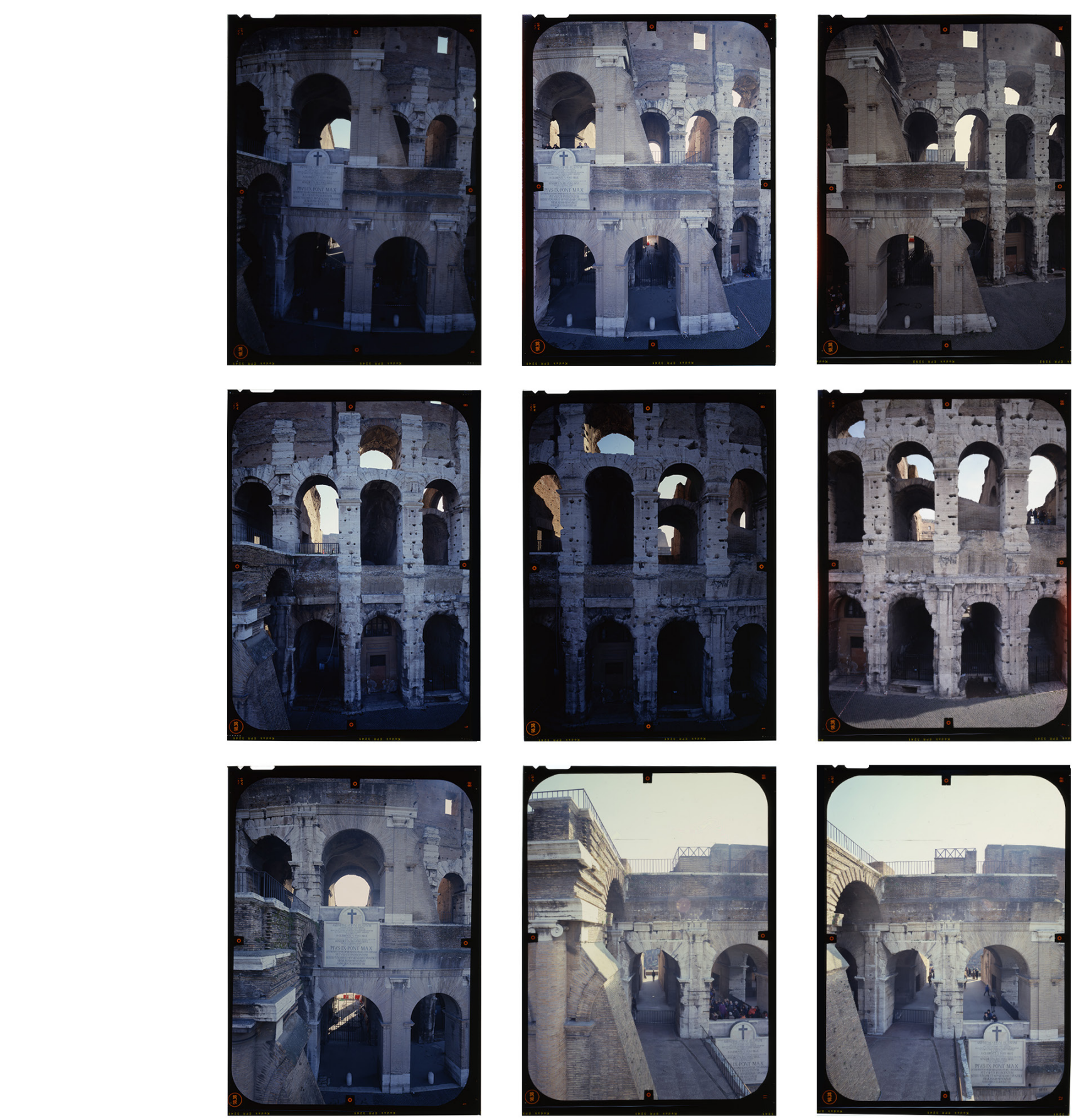

Fig. I. Survey of the Col-
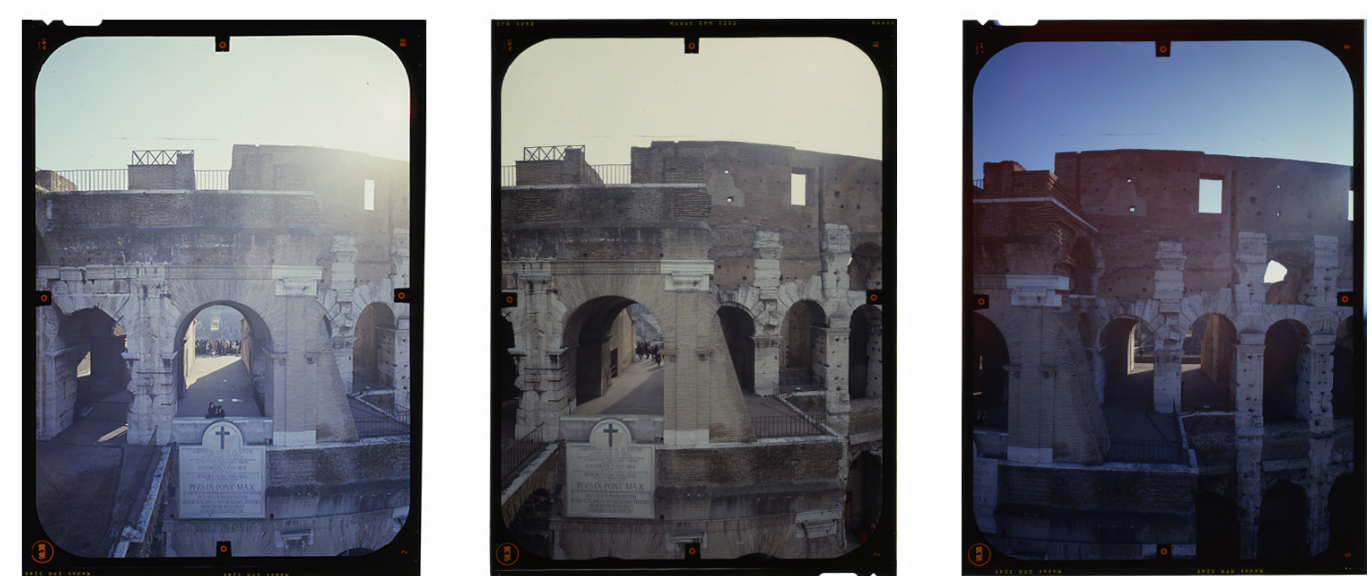


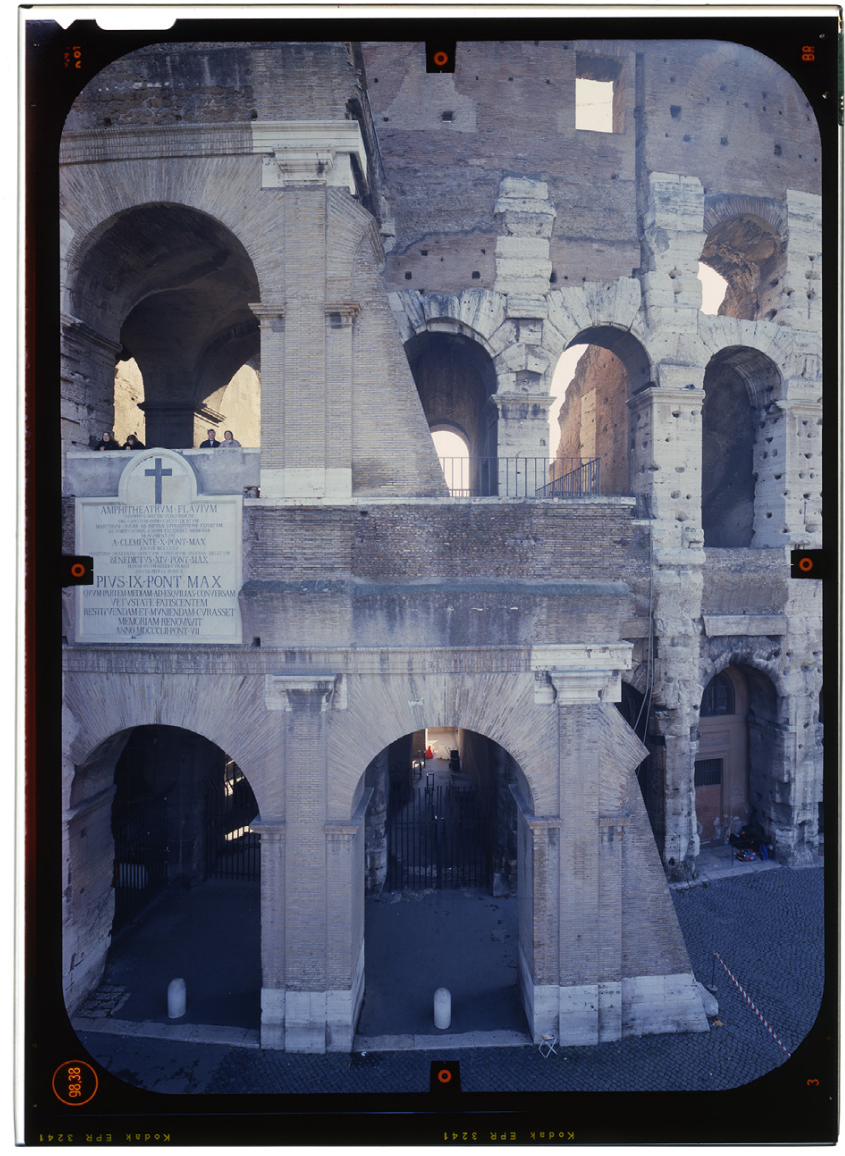

requirement is the necessary prerequisite for digital applications, including photogrammetry, related to the metric and proportional study of the image. The film-holders solve these problems with a good margin of approximation, although they do not guarantee a uniform laying out of the images on supports that are too compromised or deteriorated. The software used is the system software -Epson Scan- which allows to access and modify all the functions and scan settings to ensure greater control over the entire operation.

The main requirement in the scanning process is related to the possibility of estimating the correct value of resolution needed during the acquisition of the image, to maintain the information from the analogue photograph needed for the following phases of the experimentation. To the analog film, in fact, is not applicable the concept of resolution, linked to digital images. In this context, resolution is defined as that value which quantifies the degree of detail of an image, as a function of the number of pixels included in each unit of measurement (Pixels Per Inch). Although not perfectly comparable, the property of analog photographs that comes closest to the concept of resolution is that of image sharpness [3]. The sharpness represents the ability of the human eye to be able to distinguish the number of pairs of high-contrast lines contained in each millimeter of the image. This quality is then expressed in line pairs per millimeter, or $\mathrm{lp} / \mathrm{mm}$, (line pairs per millimeter). Conventionally, the human eye can distinguish approximately $6 \mathrm{lp} / \mathrm{mm}$ under optimal conditions, hence the custom of considering a value of $300 \mathrm{dpi}$ as optimal for good print quality. A scanner with a declared resolution of $6400 \mathrm{dpi}$ can discern up to I 25 pairs of lines per millimeter, but measurement tests on the scanner used for experimentation have shown that the lines actually observable do not exceed 40/45, for a real resolution of about 3200 dpi. 

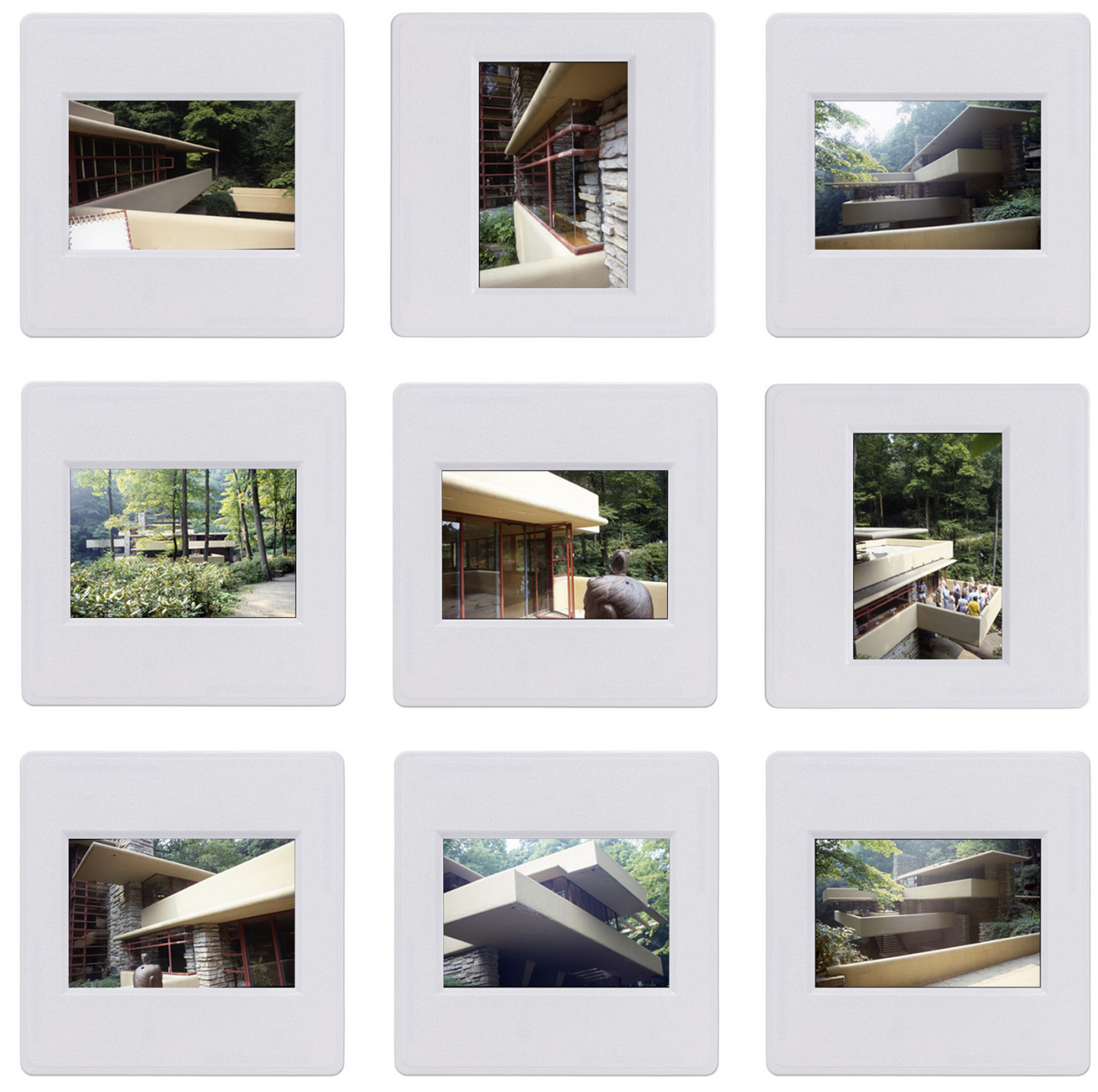

Fig. 3. Kaufmann House (Frank Lloyd Wright, 1939). $35 \mathrm{~mm}$ slides take by the author in 1987 scans at $6400 \mathrm{dpi}$.
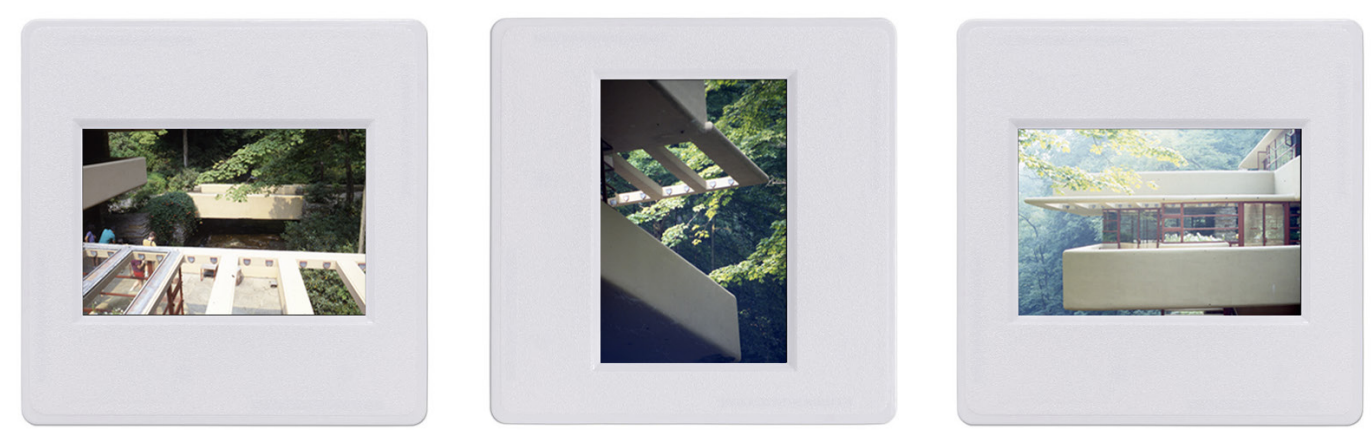

Multiplying the width of the film in millimeters by the value of sharpness expressed in $1 / \mathrm{mm}$ multiplied by 2 (for the pairs of lines) and doing the same procedure for the height, we can obtain the maximum resolution value with which, under optimal conditions, a positive can be scanned without loss of information.

$$
[(\mathrm{lpm} \times \mathrm{B} \times 2) \times(\mathrm{lpm} \times \mathrm{H} \times 2)] / 1.000 .000
$$

This approximate calculation derives from the Nyquist-Shannon sampling theorem, which defines the minimum frequency necessary to sample an analog signal without losing information [4]. 


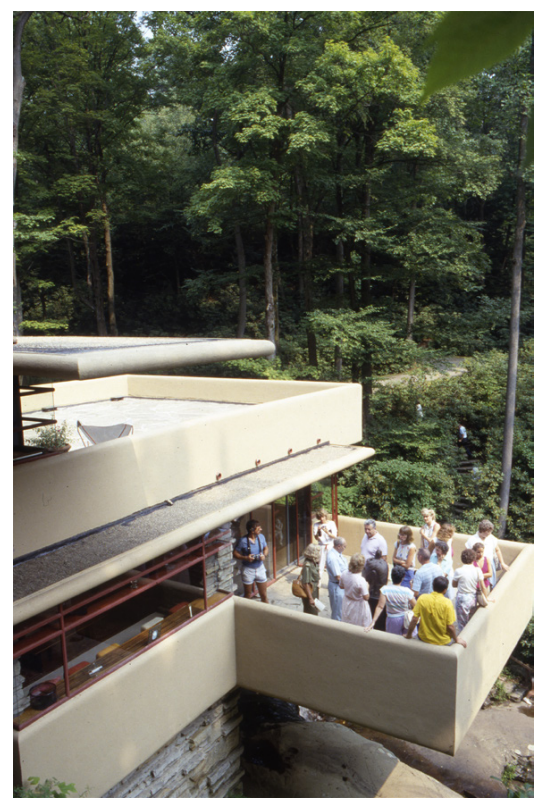

These theoretical resolutions, however, have a more articulated application. In analog images, the resolution depends on the sensitivity of the film used, while in digital images the variables are related not only to the number of pixels of the sensor, but also by the type of processing carried out by the software, peculiar to each brand of camera. Many other factors can contribute, such as the regular arrangement of the pixels of the sensor, compared to that of silver granules. Moreover, in the sensors the declared resolution is not uniform, but interpolated by zones. Empirical considerations between photographers lead to consider, for $35 \mathrm{~mm}$ film, maximum acquisition resolutions of I 5 megapixels [5].

Having said that, the experimentation was carried out on materials related to different photogrammetric survey campaigns, in order to have a heterogeneous sample of image formats.

The first case study concerns archive images acquired during a survey campaign of the Colosseum in 2000. The photogrammetric survey campaign was carried out with a Zeiss UMK 1318 metric camera, 5×7-inch Kodar EPR 324I film. Being a non-standard format of acquisition, a pressure system with a glass plate was used to ensure a homogeneous acquisition plane and to eliminate film ripples. This plate was used together with the 'film area guide', a flexible frame for films up to $8 \times 10$ ", to be placed directly on the scanner glass.

A second application involved the digital acquisition of $35 \mathrm{~mm}$ slides. The images, of amateur type acquired by means of an Olympus m20 analogue camera, depict the famous Kaufman house by Frank Lloyd Wright. In this case, the standard format allowed the use of the supplied film holder. In this case, the small size of the support favored the control of the flatness of the acquired surface.

The third sample of images concerned the archive of metric photographs of the survey of the church of Santi Domenico e Sisto in Rome, carried out in 1998. In this case, the film format is suitable for the use of the scanner's standard film holder frames, without the need for additional solutions.

Different values of slide digitization were experimented for all samples: 300dpi, I600dpi, 3200dpi and 6400dpi (highest resolution, 28864×22933 pixels, file size \pm 2 GB).

The different acquisitions were compared to each other to assess the limit beyond which an increase in scan resolution does not result in a significant increase in acquired data.

Based on these considerations, the acquisition resolution of 3200 dpi appears to be optimal for all image formats analyzed. 

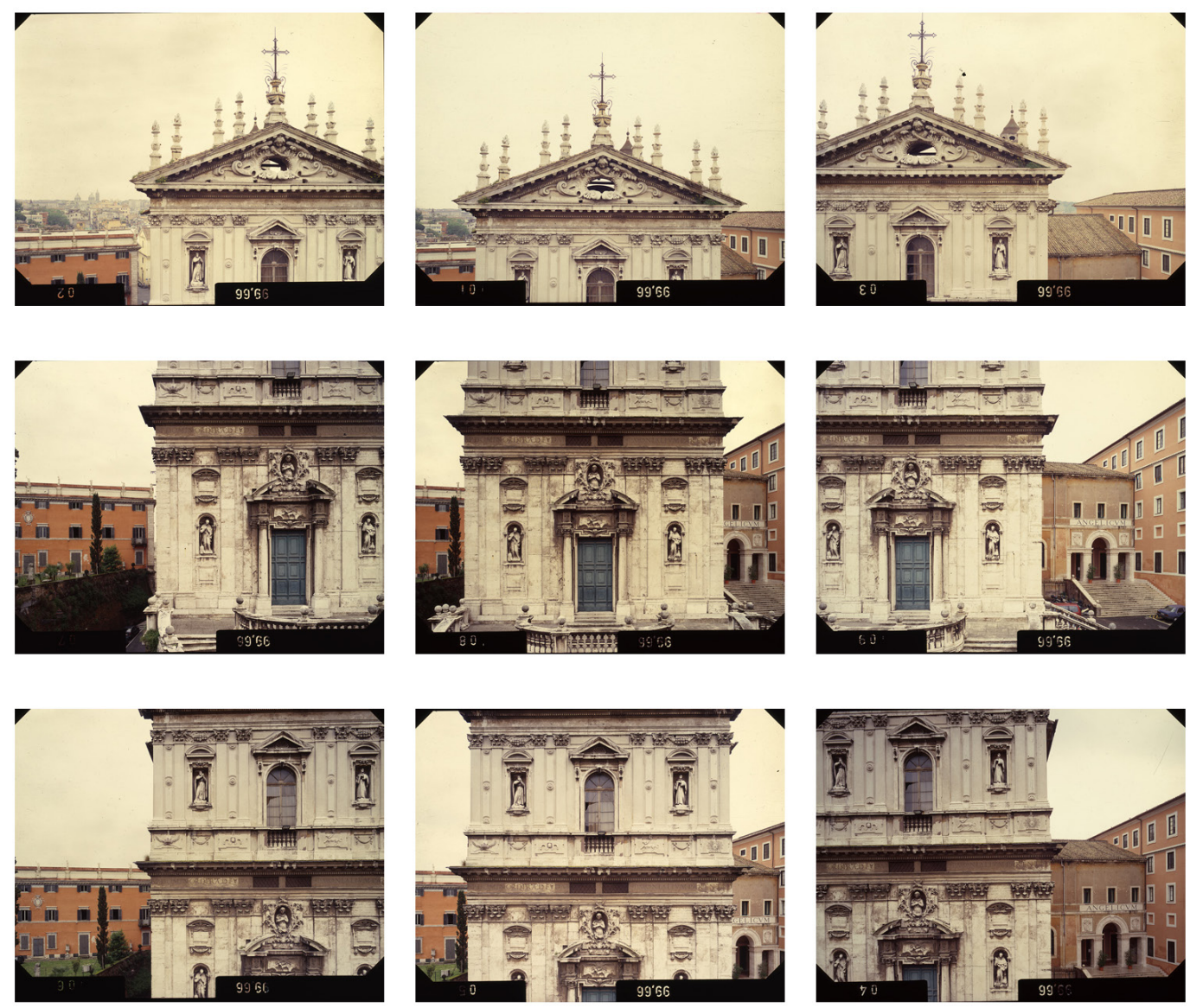

Fig. 5. Survey of the church of SS. Domenico and Sisto, 1998. Positives on $5 \times 4$ inch film taken with Wild P3! metric camera acquired with camera, acquired with scanner at $6400 \mathrm{dpi}$
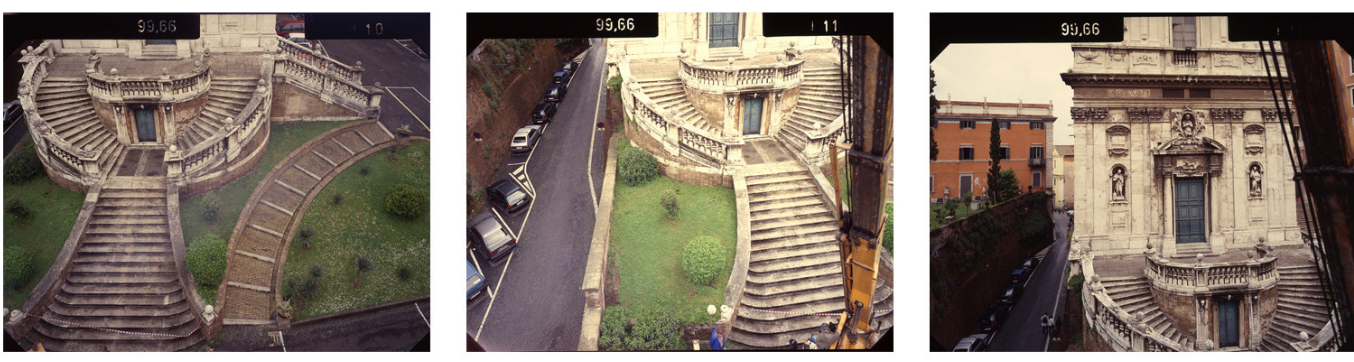

\section{New models for old acquisitions}

The acquisition procedures discussed above are the first step for the next phase of data processing. Here we present the data systematization operations for the production of new models conducted on the church of Santi Domenico e Sisto in Rome. The available documentation on the artifact dates back to a photogrammetric survey campaign conducted in 1998 by integrating the topographic acquisition with the photographic one [6]. The use of analytical photogrammetry techniques had allowed the restitution of $2 \mathrm{D}$ vector models in scale 1:50 to document all the architectural features. The graphic coding system used effectively conveys the level of reliability of restitution for each element drawn. After the first phase of reconnaissance of all the available survey material, the following phase had as objective the elaboration of a numerical model through Structure from Motion applications and, from it, of a comparison ortho-image to evaluate the morphometric correspondence with respect to the 1998 models. The use of a metric camera and the reading of the values of the fiducial points of the films allowed a precise calibration of the 

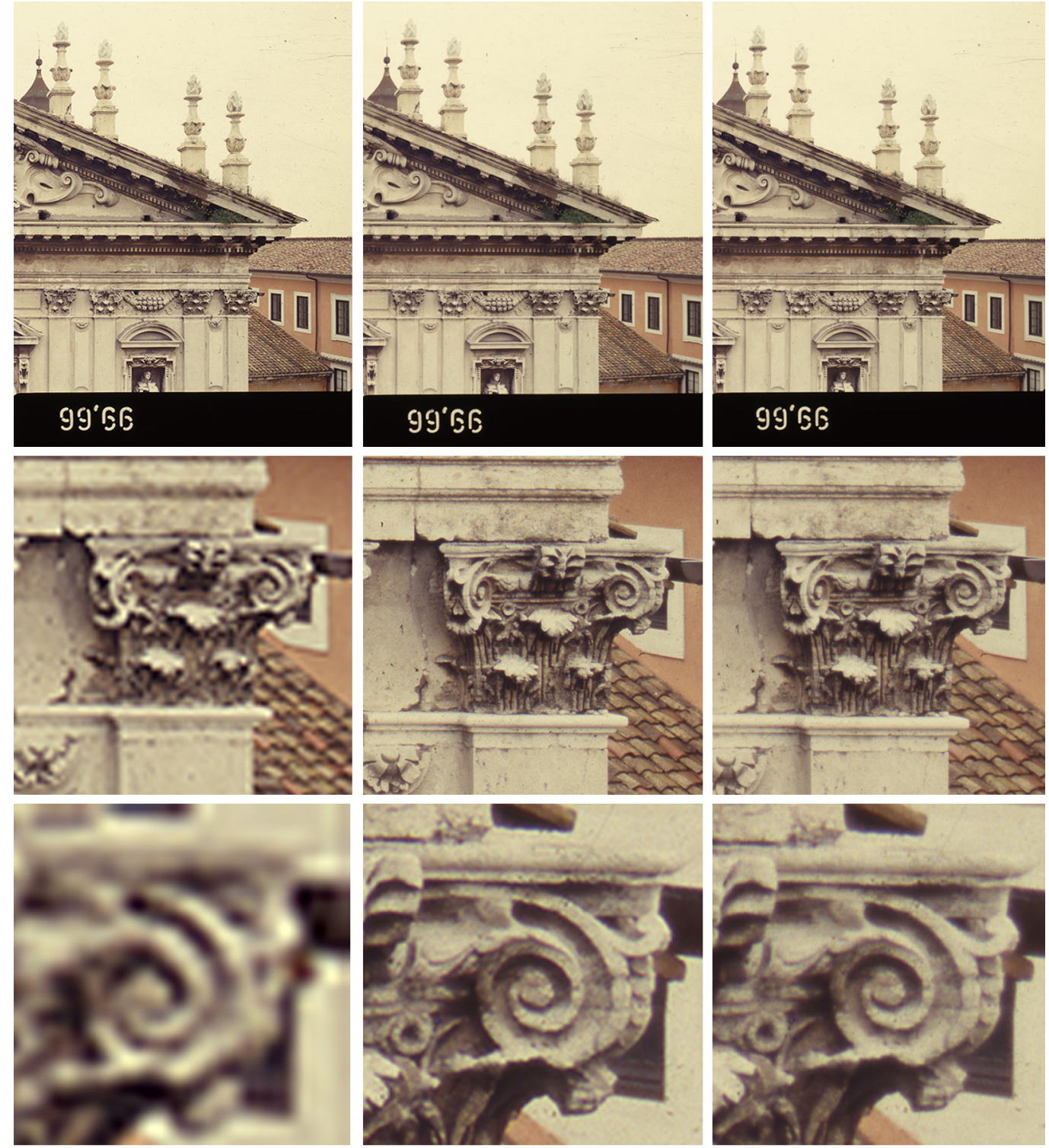

Fig. 6. Survey of the church of SS. Domenico and Sisto, 1998. Comparison of scans acquire t 300dpi (1354x 1075 pixels, weight $2.5 \mathrm{MB}$ pixels, weight $70 \mathrm{MB})$ an 64001pi $(28864 \times 22933$ 6400dpi (28864x22933 pixel, weight about 2 GB)
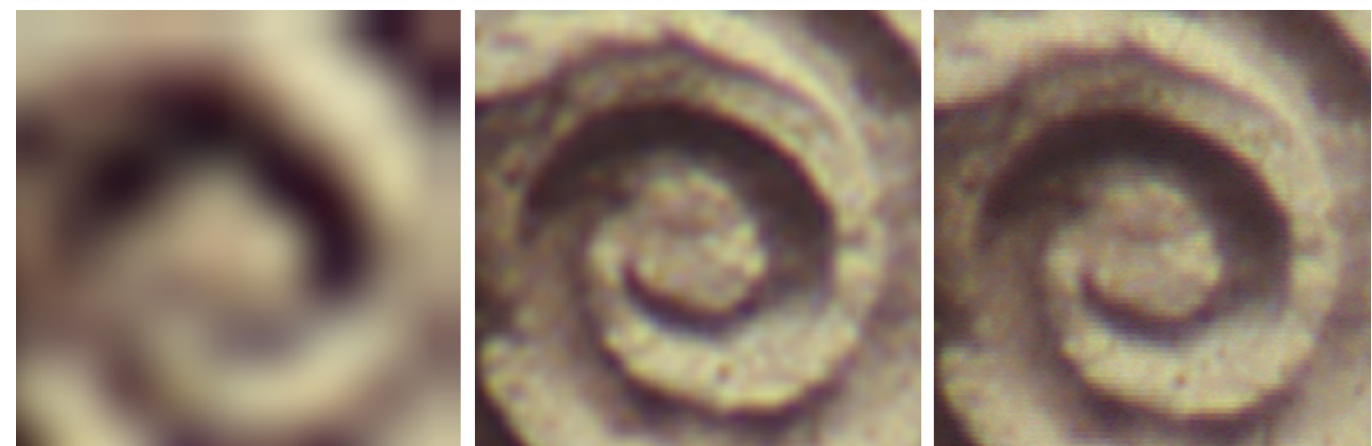


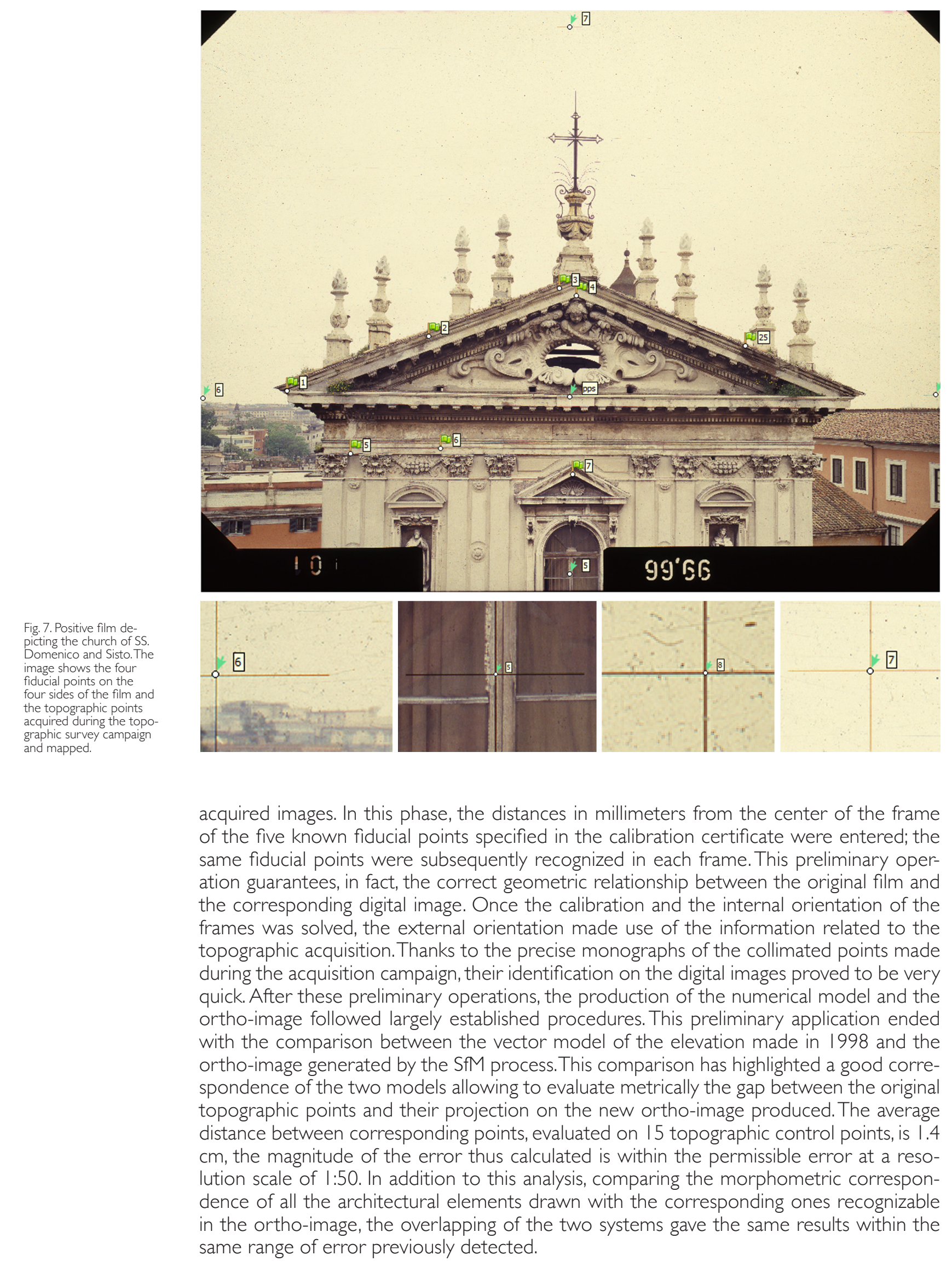


Fig. 8. On the left, Wild P3I metric camera (<http://www. wild-heerbrugg.com photogrammetryl.htm>) On the right, calibration certificate of with the scheme of the position of the fiducial position of the fiducia points and the main points of symmetry and self-collimation with respect to the central cross impressed on the film.
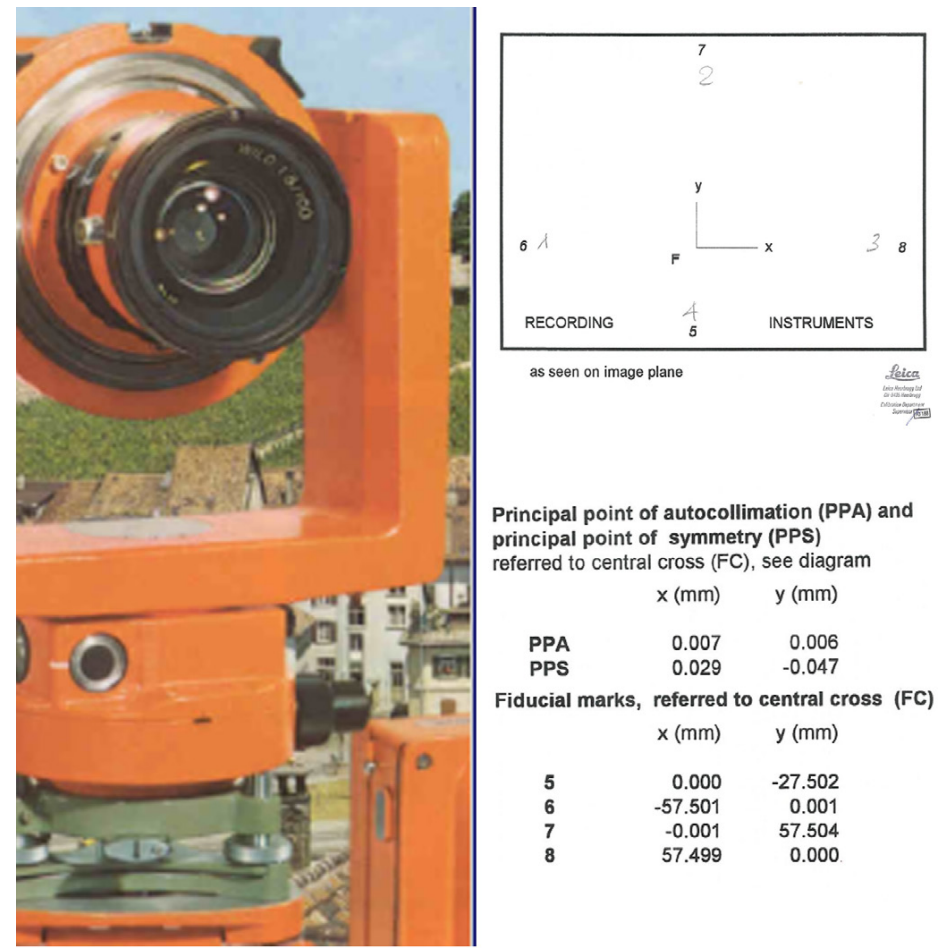

as seen on image plan

Principal point of autocollimation (PPA) and

principal point of symmetry (PPS)

referred to central cross (FC), see diagram

$x(\mathrm{~mm}) \quad y(\mathrm{~mm})$

$\begin{array}{lll}\text { PPA } & 0.007 & 0.006\end{array}$

$\begin{array}{lll}\text { PPS } & 0.029 & -0.047\end{array}$

Fiducial marks, referred to central cross (FC)

$x(\mathrm{~mm}) \quad y(\mathrm{~mm})$

$5 \quad 0.000-27.502$

$\begin{array}{lrr}6 & -57.501 & 0.001 \\ 7 & -0.001 & 57.504\end{array}$

$\begin{array}{lrr}7 & -0.001 & 57.504 \\ 8 & 57.499 & 0.000\end{array}$

\section{Conclusions}

The new digital world launch increasingly complex challenges, towards management systems of enormous quantities of data and increasingly effective information extraction methodologies. It is difficult to hide the enthusiasm in front of such disruptive prospects of progress, it is also difficult not to try to imagine first, and then experiment, applications and fallout in the most diverse areas of research. Faced with these considerations, however, comes the need to validate and keep track of data, information and models that already exist, giving them a new digital life. These transformations have often led to set aside what had already been collected and archived in favor of a new 'born-digital' documentation. In a direction that is perhaps a little less consolidated, but just as significant, the contribution aimed at imagining and experimenting with new uses and new outcomes of a considerable amount of data, information and models inherited from a not always so remote past.

\section{Notes}

[I] http://3read.it/ (accessed 202I, May 6).

[2] Dual lens flatbed scanner with 6400 dpi sensor, $216 \mathrm{~mm} \times 297 \mathrm{~mm}$ scanning range and 48 Bit color depth. The scanner is also equipped with a series of film holders for the different formats to be acquired: $35 \mathrm{~mm}$ strip, $35 \mathrm{~mm}$ framed slides, 120 strip, 4×5" format and Film Area Guide. For further information on the quality of the scanner used, refer to <http://www. effeunoequattro.net/htdocs/freecontent/FC_ProvaV700/index.htm> (accessed 202I, May 6).

[3] http://www.aristidetorrelli.it/Articoli/RisoluzionePellicolaDigitale/RisoluzionePellicolaDigitale.htm and <https://www.kenrockwell.com/tech/film-resolution.htm> (accessed 202I, May 6).

[4] <https://clarkvision.com/imagedetail/sampling l/> (accessed 2021, May 6).

[5] <http://www.stagniweb.it/scan0 I.htm> (accessed 202I, May 6).

[6] The photogrammetric survey was carried out thanks to a research contract entrusted to the Department of Representation and Survey of the University of Rome La Sapienza with the scientific coordination of Prof. Riccardo Migliari. The operations concerned the main facade of the building and were conducted using a Wild P3I metric camera with focal length 99.66 for the photographic acquisition, the Wild 1800 total station for the survey. 


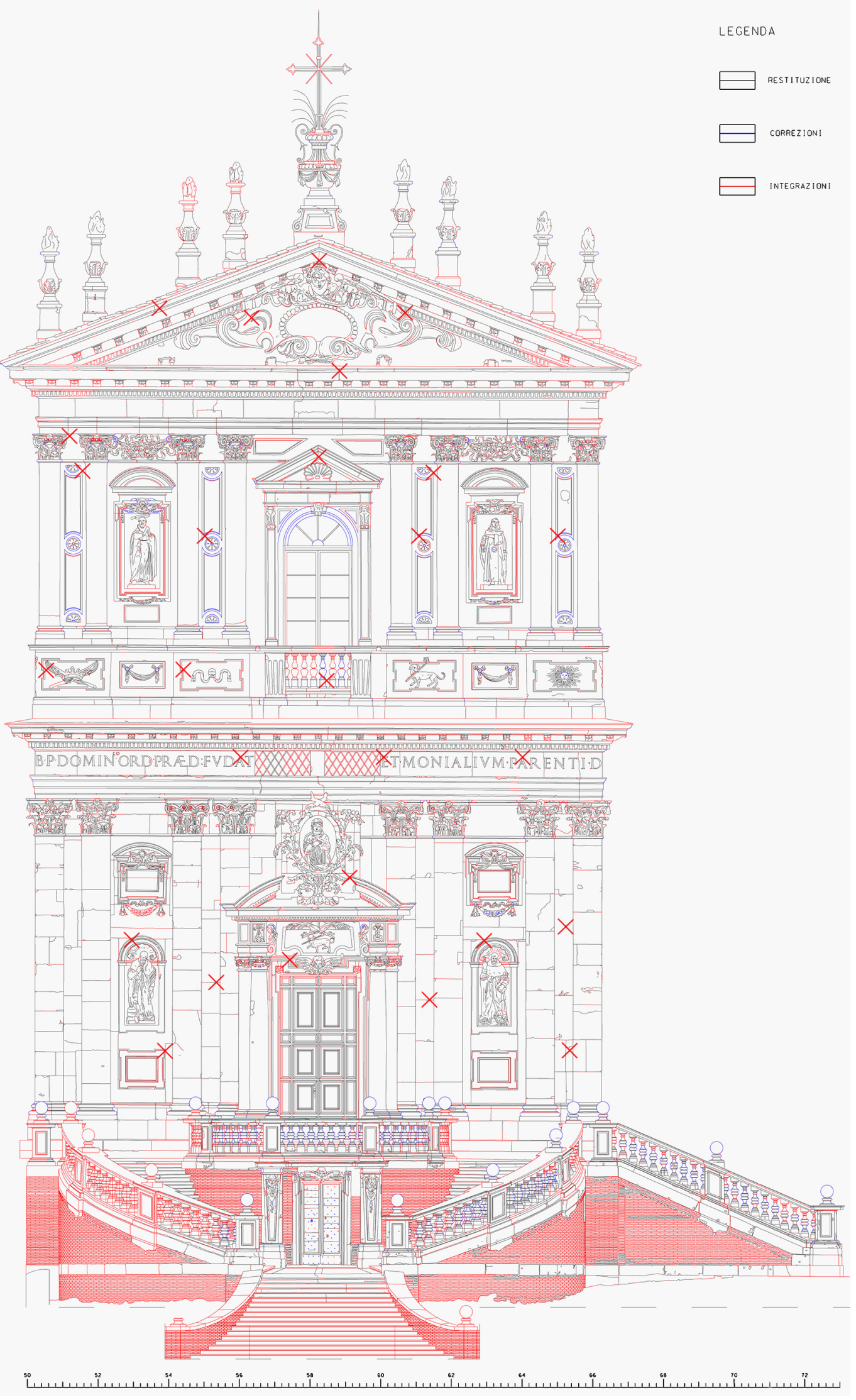




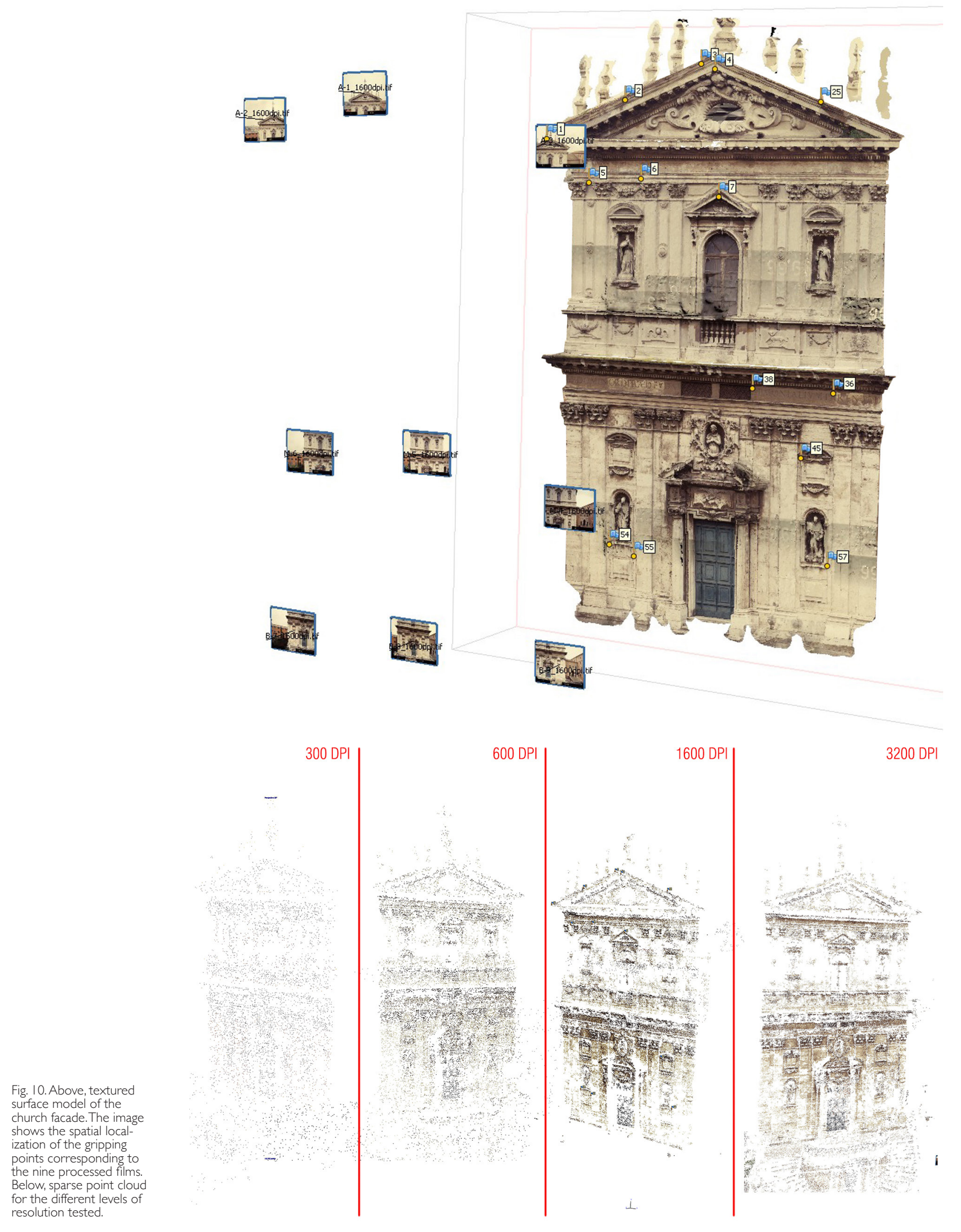


Fig. 1 1. On the left, the ortho-image realized through digital photogrammetric processes. On the right, superimposition of the 1998 restitution with the ortho-image for the metric and morphological verification of the two processed films.

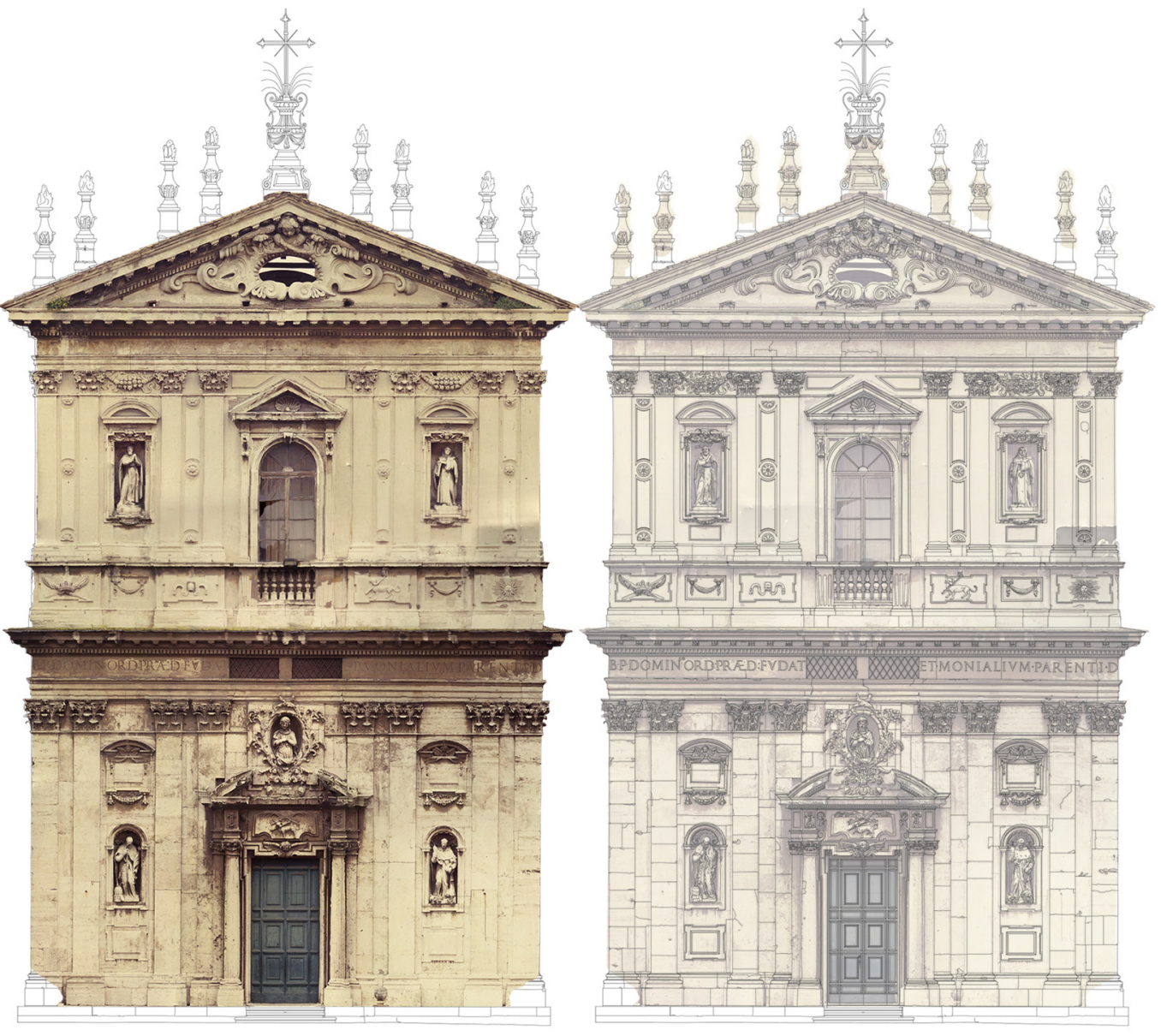

Om

$10 \mathrm{~m}$

$30 \mathrm{~m}$

\section{References}

Bianchini C. (2012). Rilievo e Metodo Scientifico.Survey and Scientific Method. Elogio della Teoria. Identità delle discipline del Disegno e del Rilievo. Roma: Gangemi Editori.

Carpiceci M. (2012). Fotografia digitale e architettura. Storia, strumenti ed elaborazioni con le odierne attrezzature fotografiche e informatiche, pp. 94- | 14. Roma: Aracne Editrice.

Dlesk D., Uueni A., Vach K. et al. (2020). From Analogue to Digital Photogrammetry: Documentation of Padise Abbey in Two Different Time Stages. In MDPI Applied Science, n. I0(23), 8330, pp. I - 6.

Dlesk A., Vach K., Pavelka K. (2020). Structure from motion processing of analogue images captured by Rollei metric camera, digitized with various scanning resolution. In Acta Polytechnica, 2020, 60.4, pp. 288-302

Nichols J., Fong D., Avey S. (20 I 6). Re-Envisioning Lost Built Cultural Heritage: POST-Tsunami Aceh. In International Conference on Engineering and Science for Research and Development (ICESReD). Proceeding Banda Aceh international conference on engineering and science for research and development. Banda Aceh - Indonesia October 25, 26, 2016, pp. 83-93.

Valenti G. M. (2019). Digital models: divulgation and dissemination. In Parrinello S. Digital \& Documentation. Databases and Models for the enhancement of Heritage, pp. 44-55. Pavia: Pavia University Press.

\section{Authors}

Carlo Bianchini, Sapienza Università di Roma, carlo.bianchini@uniromal.it

Alekos Diacodimitri, Sapienza Università di Roma, alekos.diacodimitri@uniromal.it

Marika Griffo, Sapienza Università di Roma, marika.griffo@uniromal.it

To cite this chapter. Bianchini Carlo, Diacodimitri Alekos, Griffo Marika (2021). Lost in conversion. Gli archivi fotografici tra analogico e digitale/Lost in Conversion. Photographic Archives between Analogue and Digital. In Arena A.,Arena M. Mediati D. Raffa P. (a cura di). Connettere. Un disegno per annodare e tessere Linguagri Distanze Tecnologie Atti del $42^{\circ}$ Convegno Internazionale dei Docenti delle Discipline della Rappresentazione/Connecting Drawing for weaving relationship. Languages Distances Technologies. Proceedings of the 42th International Conference of Representation Disciplines Teachers. Milano: FrancoAngeli, pp. 2036-206I. 